Published in final edited form as:

Curr Top Behav Neurosci. 2009 ; 1: 309-346. doi:10.1007/978-3-540-88955-7_13.

\title{
Drug Addiction
}

\author{
Zuzana Justinova $^{1,2}$, Leigh V. Panlilio ${ }^{1}$, and Steven R. Goldberg ${ }^{1}$ \\ ${ }^{1}$ Preclinical Pharmacology Section, Behavioral Neuroscience Research Branch, Intramural \\ Research Program, National Institute on Drug Abuse, National Institutes of Health, Department of \\ Health and Human Services, Baltimore, MD 21224, USA \\ ${ }^{2}$ Maryland Psychiatric Research Center, Department of Psychiatry, University of Maryland School \\ of Medicine, Baltimore, MD 21228, USA
}

\begin{abstract}
Many drugs of abuse, including cannabinoids, opioids, alcohol and nicotine, can alter the levels of endocannabinoids in the brain. Recent studies show that release of endocannabinoids in the ventral tegmental area can modulate the reward-related effects of dopamine and might therefore be an important neurobiological mechanism underlying drug addiction. There is strong evidence that the endocannabinoid system is involved in drug-seeking behavior (especially behavior that is reinforced by drug-related cues), as well as in the mechanisms that underlie relapse to drug use. The cannabinoid $\mathrm{CB}_{1}$ antagonist/inverse agonist rimonabant has been shown to reduce the behavioral effects of stimuli associated with drugs of abuse, including nicotine, alcohol, cocaine, and marijuana. Thus, the endocannabinoid system represents a promising target for development of new treatments for drug addiction.
\end{abstract}

\section{Introduction}

\subsection{Drug addiction}

The abuse of drugs and alcohol is a major problem worldwide, costing 250 billion dollars annually due to premature deaths, healthcare expenditures, reduction of productivity, lost earnings and drug-related crime in the United States alone (estimated by U.S. National Institute on Drug Abuse and National Institute on Alcohol Abuse and Alcoholism). Drug addiction is considered to be a chronic, relapsing disorder characterized by compulsive drugseeking, by continued use despite serious negative socioeconomic and health consequences, and by loss of control over drug use (Cami and Farre 2003). The World Health Organization and the American Psychiatric Association use the term "substance dependence" rather than "drug addiction". Both terms are used interchangeably in the literature, but the latter term is less likely to be confused with physical dependence and emphasizes the behavioral component of the process. According to the DSM-IV (American Psychiatric Association 1994), three or more of the following must be present in order to diagnose substance dependence: a) symptoms of tolerance, b) symptoms of withdrawal, c) large amounts of drug taken, d) unsuccessful attempts or desire to control use, e) considerable time spent obtaining the substance, f) reduction of social and occupational activities due to abuse, g) continued use of a substance despite physical or psychological problems.

Repeated drug use arises from the drug's neurochemical actions that produce positive reinforcing effects, progressively leading to neurobiological changes in the brain reward circuits and behaviors characteristic of addiction: tolerance, sensitization, dependence, withdrawal and craving (Kreek et al. 2002). The transition from casual drug use to drug addiction might also involve an additional source of reinforcement, such as the reduction of a negative emotional state during acute abstinence (Koob et al. 1998). The combination of 
positive (e.g., euphoria) and negative (e.g., alleviation of dysphoria or withdrawal symptoms) reinforcement may provide a powerful motivational force for compulsive drug taking. Associated neurobiological changes and behavioral abnormalities and deficits in cognitive function may persist for months or years after discontinuation of drug use (Cami and Farre 2003).

\subsection{Endocannabinoid system in brain reward circuitry}

The initial events that lead to drug addiction involve acute effects at the specific sites of action of the abused drug. These sites of action (e.g., G-protein coupled receptors and ligand-gated ion channels) typically activate neural circuits associated with positive reinforcement/reward, particularly the mesocorticolimbic dopaminergic system. This system, originating in the ventral tegmental area (VTA) and projecting to the nucleus accumbens, olfactory tubercle, frontal cortex, and amygdala (Wise 2004), interacts with glutamatergic projections from the cerebral cortex, hippocampus, and amygdala, and thus regulates responses to natural reinforcers such as food, drink, social interactions or sex (Kauer 2004). The mesocorticolimbic dopaminergic system is part of a brain reward circuit that has long been thought to play a major role in mediating the reinforcing/rewarding effects of drugs of abuse (Di Chiara et al. 1999; Koob 1992; Wise and Bozarth 1987). Abused drugs (like opioids, cannabinoids, psychostimulants, alcohol, nicotine, sedativehypnotics, anxiolytics, and anesthetics) directly or indirectly elevate extracellular levels of dopamine in the shell of the nucleus accumbens (Brodie et al. 1999; Chen et al. 1990; Masuzawa et al. 2003; Pontieri et al. 1995; Pontieri et al. 1996; Spyraki and Fibiger 1988; van der Laan et al. 1992).

In the striatum, cannabinoid $\mathrm{CB}_{1}$ receptors are localized presynaptically in GABAergic and glutamatergic nerve terminals, but also postsynaptically in the dendritic shafts and spines of both, enkephalinergic and dynorphinergic, GABAergic efferent neurons (Fusco et al. 2004; Hohmann and Herkenham 2000; Kofalvi et al. 2005; Pickel et al. 2004; Pickel et al. 2006). When these cells are depolarized, endocannabinoids can be released in the nucleus accumbens (Robbe et al. 2001) and VTA (Melis et al. 2004; Riegel and Lupica 2004), where they modulate the excitatory (glutamatergic) and inhibitory (GABAergic) inputs that control dopaminergic neurons of the mesocorticolimbic pathway by acting as retrograde messengers on $\mathrm{CB}_{1}$ receptors. Endocannabinoids are also involved in synaptic plasticity in the mesolimbic system - please see the chapter, "Endocannabinoid signaling in neural plasticity".

The dopaminergic system has a well-established role in the reinforcing effects of drugs of abuse. It has become increasingly clear that the endocannabinoid system can modulate dopaminergic reward circuits, which suggests that endocannabinoids also play a major role in the mechanisms underlying drug addiction.

\subsection{Release of endocannabinoids by abused drugs}

The endocannabinoid system can modulate the primary rewarding effects of noncannabinoid drugs of abuse, and this ability appears to depend on endocannabinoid release in the VTA (Lupica and Riegel 2005). This hypothesis is consistent with evidence that repeated non-contingent drug administration alters levels of the endocannabinoids anandamide and 2-arachidonoylglycerol (2-AG).

Analysis of anandamide and 2-AG levels in brains of animals treated chronically with cocaine, nicotine, or ethanol showed that chronic cocaine administration produced a modest but significant decrease in the content of 2-AG in the limbic forebrain (Gonzalez et al. 2002). In contrast, chronic ethanol and nicotine exposure produced an increase in 
anandamide content in this area. Chronic ethanol administration caused a decrease in the contents of both anandamide and 2-AG in the midbrain. Chronic nicotine exposure increased both anandamide and 2-AG in the brainstem and decreased their content in the hippocampus, striatum and cerebral cortex. It appears that the most consistent finding with these drugs of abuse is that chronic administration led to an elevation in endocannabinoid levels in the limbic system. This observation is consistent with the notion that endocannabinoids enhance the reinforcing effects of addictive drugs by increasing dopamine release via the inhibition of GABA release in the limbic system. Chronic administration of $\Delta^{9}$-tetrahydrocannabinol (THC) itself decreases the levels of anandamide and 2-AG in the striatum (Di Marzo et al. 2000). Chronic morphine administration decreases 2-AG levels in the striatum without altering anandamide levels (Gonzalez et al. 2003; Vigano et al. 2003). Acute morphine administration, on the other hand, increased anandamide levels and decreased 2-AG levels in the striatum (Vigano et al. 2004). Thus, the selection of the time point for endocannabinoid analysis is critical for determination of the nature of alterations in endocannabinoid levels.

It should be noted that, in the studies just described, endocannabinoid levels were measured in postmortem rat brain tissue, usually at a single time-point after chronic administration of the drugs. Therefore, it is not clear whether these findings reflect sustained changes in the brain endocannabinoid levels, or acute alterations of endocannabinoid formation. Another potential problem with these results is that endocannabinoid levels in brain tissue are affected by rapid postmortem increases in endocannabinoid formation (Bazinet et al. 2005; Patel et al. 2005). In addition, these studies have used non-contingent drug administration, which can produce neurochemical, proteomic, and genomic effects that differ substantially from those induced by free-choice self-administration (Jacobs et al. 2003). Thus, further research is required to determine whether endocannabinoid levels would be affected in the same way if the drugs were self-administered

In vivo microdialysis techniques offer an effective means of studying levels of neurotransmitters during drug self-administration. However, microdialysis is difficult to perform with anandamide and 2-AG due to their highly lipophilic nature and instability. The first study in which endocannabinoid levels were measured by microdialysis showed that local intrastriatal administration of the dopamine $\mathrm{D}_{2}$ agonist quinpirole elevated levels of anandamide, but not 2-AG (Giuffrida et al. 1999). Caille and colleagues (Caille et al. 2007) were the first to measure changes in endocannabinoid levels during self-administration of a drug of abuse. They found that self-administration of cocaine did not alter either anandamide or 2-AG levels in the nucleus accumbens, but self-administration of heroin increased anandamide and decreased 2-AG levels, and self-administration of ethanol increased 2-AG without altering anandamide levels. These data provide in vivo evidence for an endocannabinoid involvement in the motivational effects of ethanol and heroin but not cocaine.

An exciting new analytical method, combining online in vivo brain microdialysis with solidphase extraction-liquid chromatography-tandem mass spectrometry, allows real-time detection of trace amounts of endocannabinoids in the extracellular fluid. This technique has been used to show that the $\mathrm{CB}_{1}$ receptor antagonist/inverse agonist rimonabant increased, whereas the $\mathrm{CB}_{1}$ receptor agonist WIN 55,212-2 decreased, anandamide release in the rat hypothalamus (Bequet et al. 2007). Interestingly, the same treatments induced opposite changes in 2-AG release. The same study also shows that inhibition of fatty acid amide hydrolase (FAAH), the primary enzyme responsible for anandamide degradation, induced an increase in outflow of anandamide, but not 2-AG. In this study, FAAH was inhibited by systemic administration of URB597, a selective FAAH inhibitor now entering clinical trial. 


\subsection{Endocannabinoids in drug-seeking and relapse}

Relapse to drug use, even after a long period of forced or voluntary withdrawal and detoxification, is one of the defining features of addiction, and perhaps the most important impediment to effective treatment (American Psychiatric Association 1994; O'Brien 2001). Reinstatement of drug-seeking behavior in laboratory animals is an experimental procedure that is used to model relapse. In this model, animals are initially trained to self-administer drugs intravenously by making an operant response (e.g., pressing a lever). Subsequently, the drug-reinforced behavior is extinguished by replacing the self-administered drug solution with saline or by disconnecting the infusion pump. After extinction of the drugreinforced behavior, reinstatement of drug-seeking behavior can be tested by one of several procedures that mirror the triggers that induce relapse in humans. These include noncontingent injection of a drug (drug-induced reinstatement), presentation of visual or auditory stimuli that had previously signaled availability or delivery of the drug (cueinduced reinstatement), or exposure to a brief period of intermittent foot-shock in the selfadministration chamber (stress-induced reinstatement).

The first evidence for involvement of the endocannabinoid system in reinstatement of extinguished drug-seeking behavior was provided by De Vries and colleagues (De Vries et al. 2001). They found that the synthetic $\mathrm{CB}_{1}$ receptor agonist HU210 could reinstate cocaine-seeking behavior. The $\mathrm{CB}_{1}$ antagonist/inverse agonist rimonabant blocked this effect and also reduced cocaine- and cue-induced reinstatement, but not stress-induced reinstatement. Another $\mathrm{CB}_{1}$ antagonist/inverse agonist, $\mathrm{AM} 251$, was later found to block cocaine-induced reinstatement of drug-seeking behavior (Xi et al. 2006). Rimonabant has since been found to reduce reinstatement induced by heroin, methamphetamine, nicotine, WIN 55,212-2 and ethanol, and to attenuate or block cue-induced reinstatement of the seeking of cocaine, nicotine, heroin, methamphetamine, and alcohol in rodents (De Vries and Schoffelmeer 2005; Fattore et al. 2007). Rimonabant blocks both THC-induced and cueinduced reinstatement of THC-seeking behavior in non-human primates (Justinova et al. 2008b). At present, studies investigating a potential ability of $\mathrm{CB}_{1}$ receptor blockade to alter reinstatement have been described as indicating that rimonabant is unable to affect stressinduced relapse to cocaine or ethanol seeking (Fattore et al. 2007). Although stress-induced relapse has received less attention than drug- and cue-induced relapse, the evidence accumulated to date indicates that endocannabinoid signaling might not be involved in stress-induced reinstatement.

Early clinical trials examining the effectiveness of rimonabant as an aid in smoking cessation and obesity treatment were very promising. Rimonabant has been approved and marketed as an anti-obesity treatment, but not an anti-smoking treatment, in the European Union and in a number of other countries. However, in 2006 the American Food and Drug Administration (FDA) declined to approve rimonabant for smoking cessation and required further studies before final approval for weight management. This was due to concerns over possible depression-like side effects. It has been suggested that $\mathrm{CB}_{1}$ neutral antagonists may be devoid of the side effects produced by $\mathrm{CB}_{1}$ antagonists/inverse agonists, and neutral antagonists are now being tested in animal studies (Salamone et al. 2007; Sink et al. 2008). Thus, while manipulations of the endocannabinoid system show promise for the treatment of addiction, there is not yet a specific clinically tested compound that has been shown to be both effective and safe.

\section{Cannabinoids}

Cannabinoids, usually abused by humans in the form of marijuana, have become the most frequently abused illicit class of drugs in the United States. There is ample evidence that most of the centrally mediated effects of cannabinoids occur through the endocannabinoid 
system. The effects of marijuana in humans are quite complex and highly variable depending on the dose of the drug, environment and expectations of the user. The subjective effects may include excitement and dissociation of ideas, quickening of mental associations, heightened perception, distortion of the sense of time, irresistible impulses and illusions accompanied by decrease of psychomotor activity (Dewey 1986). In addition to its euphorigenic properties (Haney et al. 1997), marijuana can produce anxiety, analgesia, hypothermia, increased appetite, anti-emetic effects, vasorelaxation, and alterations in cognition and memory (Hollister 1986). A controlled study in healthy cannabis users showed that the intoxicant effects are clearly mediated by $\mathrm{CB}_{1}$ receptors (Huestis et al. 2001). In rodents, administration of cannabis or its major psychoactive ingredient, THC, produces a characteristic combination of four signs, analgesia, hypoactivity, catalepsy, and hypothermia, associated with anxiogenesis, memory changes and cardiovascular changes (Chaperon and Thiebot 1999). The tetrad of behavioral and physiological assays (motor activity, ring catalepsy, body temperature and analgesia tests) was developed to assess in vivo activity of cannabinoid analogs in mice (Martin et al. 1991). In monkeys, disruption of behavior and static ataxia have also been observed (Branch et al. 1980).

Although cannabis dependence is often considered to be a less serious problem than dependence on other drugs, the number of people seeking treatment for cannabis use in the U.S. is higher than the number seeking treatment for cocaine use (CEWG 2007; Substance Abuse and Mental Health Services Administration 2007). Cannabis produces clear subjective motivational responses in humans, leading to drug-seeking and drug-taking behavior (Maldonado 2002). Many different animal models are used to elucidate the consequences of chronic exposure to cannabinoids and to predict their abuse liability. Tolerance and withdrawal syndromes provide only a partial correlate of their addictive properties. The reinforcement-related motivational properties of drugs, including cannabinoids, can be evaluated using several different behavioral models: drug selfadministration, conditioned-place preference/aversion and drug-discrimination paradigms.

\subsection{Self-administration of cannabinoids}

2.1.1 Drug self-administration paradigm-Drug self-administration behavior is one of the most direct and productive approaches for studying the reinforcing effects of psychoactive drugs, which are critical in determining their abuse potential (Johanson and Balster 1978). Even in a non-dependent state, animals and humans will readily selfadminister drugs of abuse. Allowing limited access to drugs provides a reliable model for their acute reinforcing effects and a means for exploring the neuropharmacological mechanisms involved in these effects (Koob and Weiss 1990). Reliable and persistent selfadministration behavior has now been demonstrated in laboratory animals for almost all drugs abused by humans, including psychostimulants, opiates, ethanol, nicotine (Collins et al. 1984; Goldberg et al. 1981; Koob and Weiss 1990; Yokel 1987; Young and Herling 1986), and recently marijuana (THC) (Justinova et al. 2003; Justinova et al. 2008b; Tanda et al. 2000).

During the intravenous self-administration procedure, animals are allowed to self-administer a drug by making an operant response, such as pressing a lever or inserting their nose into a hole (a "nose-poking" response), which activates a pump to intravenously deliver the drug. Subjects are prepared with intravenous catheters. Primates often wear a vest to protect the catheter. In many studies, a certain number of responses is required for each injection, in a procedure known as a fixed-ratio schedule. The behavioral measures in drug selfadministration studies include the rate of responding and the number of drug injections delivered. Although there are many variations of the self-administration paradigm, usually the reinforcing efficacy of a tested drug is compared to a standard drug of known abuse 
potential from a similar pharmacological class and also to the drug's vehicle in the same subject (Bergman and Johanson 1985; Tanda et al. 2000; Young and Woods 1981). These studies are often performed in rhesus (Macaca mulatta) or squirrel (Saimiri sciureus) monkeys, which have learned to self-administer a drug, for example cocaine, under a schedule requiring a certain number of responses to obtain each injection (e.g., 10-response, fixed-ratio schedule of drug injection) (Goldberg et al. 1971). The drugs being tested are then substituted for the training drug and evaluated for their ability to maintain a level of responding resulting in their frequent injection. It is important to mention that the functional state of the brain reward circuits in naïve versus experienced drug self-administering animals is different, and neurobiological adaptations might predispose to or limit subsequent self-administration (Young et al. 1981).

To study the relative reinforcing efficacy of drugs and compare the effects of pharmacological treatments, progressive-ratio schedules of drug self-administration are often used, in which the number of responses required for each injection increases progressively within a session until the drug-seeking response ceases (Arnold and Roberts 1997). Progressive-ratio schedules allow an estimation of the maximal effort an individual will put forth under a specified set of conditions to obtain a particular reinforcement. The behavioral measure obtained is the maximal number of responses an animal will perform for a single drug injection, often called the "break-point," which is taken as a measure of the motivational strength of the reinforcing event and predicts rewarding efficacy of drugs (Hodos 1961). Many different and more complicated schedules of reinforcement also exist and are used to focus on various aspects of addiction. One of these variations, the second order schedule, is discussed in detail in section 2.1.3.

\subsubsection{Fixed-ratio schedule}

2.1.2.1 THC and synthetic cannabinoids: During the last three decades, many attempts to demonstrate intravenous self-administration of THC or of synthetic $\mathrm{CB}_{1}$ receptor agonists by experimental animals were relatively unsuccessful (for review see (Justinova et al. 2005a; Tanda and Goldberg 2003). In none of these studies were THC or synthetic cannabinoids clearly shown to maintain self-administration behavior that was persistent, dose-related and susceptible to vehicle extinction and subsequent reinstatement. Only a few studies reported self-administration of THC at levels higher than vehicle controls. In one of these studies (Kaymakcalan 1973), two monkeys out of six acquired THC self-administration behavior, but only after withdrawal from forced automatic intravenous injections of THC, when overt signs of physical dependence occurred.

Although THC has not been found to maintain persistent intravenous self-administration in mice or rats, it has been reported to be self-administered intracerebroventricularly (Braida et al. 2004) and into the VTA and the shell of the nucleus accumbens (Zangen et al. 2006) in rats. There have also been several reports of intravenous and intracerebroventricular selfadministration of synthetic $\mathrm{CB}_{1}$ receptor agonists in rodents: WIN 55,212-2 (Ledent et al. 1999; Martellotta et al. 1998), CP 55,940 (Braida et al. 2001b; Navarro et al. 2001), and HU-210 (Navarro et al. 2001) in mice and of WIN55,212-2 in rats (Fattore et al. 2001; Spano et al. 2004). However, the experimental procedures employed in some of these studies limit the scope and generality of the findings. For example, the studies with mice (Ledent et al. 1999; Martellotta et al. 1998; Navarro et al. 2001) employed one-day experimental tests during which mice were restrained for acute intravenous administration through the tail vein. This procedure provides little information about acquisition, extinction and relapse to self-administration behavior. In contrast, the study by Fattore and colleagues (Fattore et al. 2001) utilized unrestrained, freely-moving rats as subjects that were allowed to self-administer WIN 55,212-2 over repeated daily sessions. Spano and colleagues (Spano 
et al. 2004) used the same model to provide the first evidence of drug-induced reinstatement of cannabinoid-seeking behavior.

It is important to note that chronic diet restriction (rats were maintained at $80 \%$ of their normal body weight) was a necessary condition in the study by Fattore and colleagues (Fattore et al. 2001), since rats on an unrestricted diet did not acquire cannabinoid selfadministration behavior. Diet restriction has been repeatedly shown to increase a wide variety of appetitive behaviors, including self-administration of drugs from each of the major classes of abused drugs (Carroll and Meisch 1984). Thus, the need for food restriction may simply indicate that cannabinoid agonists are only weakly reinforcing in rats, or that they may have aversive effects that can counteract their reinforcing effects. In another series of studies, food was not only restricted in the rats, but delivered during the THC selfadministration sessions (Takahashi and Singer 1979; Takahashi and Singer 1980). In those studies, THC self-administration behavior above placebo levels was found in diet-restricted rats (maintained at $80 \%$ of normal body weight), under conditions where a food pellet was automatically delivered once every minute. However, this self-administration behavior immediately decreased to placebo levels when food restriction was discontinued, suggesting that this was probably a schedule-induced adjunctive behavior, rather than a case of drug reinforcement, per se.

Robust, dose-related, intravenous self-administration of THC by animals was first demonstrated under a fixed-ratio schedule in squirrel monkeys (Tanda et al. 2000). This study utilized monkeys with cocaine self-administration experience that were not food deprived and had access to THC only after at least one week of saline extinction. The dose range of THC in this study (1-8 $\mu \mathrm{g} / \mathrm{kg} /$ injection) was lower than that previously used in THC self-administration studies and comparable to that received from smoking a marijuana cigarette (Agurell et al. 1986; Tanda et al. 2000). Under these conditions, monkeys readily acquired THC self-administration behavior. Once acquired, self-administration behavior could be rapidly extinguished by substituting vehicle for THC or by administering the $\mathrm{CB}_{1}$ antagonist/inverse agonist, rimonabant, suggesting that the behavior was mediated by $\mathrm{CB}_{1}$ receptors. The opioid-receptor antagonist naltrexone can also partially reduce THC selfadministration (Justinova et al. 2004).

Although earlier attempts to obtain THC self-administration behavior in monkeys that had prior experience with cocaine self-administration were unsuccessful - even when THC was directly substituted for cocaine with no intervening vehicle extinction (Harris et al. 1974) the fact that the monkeys in the study by Tanda and colleagues (Tanda et al. 2000) had prior experience with cocaine raised the possibility that cocaine might induce persistent neurobiological adaptations that subsequently predispose animals to self-administer THC (Maldonado 2002). However, such adaptations are clearly not a necessary condition, since further experiments established that drug-naïve squirrel monkeys readily acquired THC selfadministration behavior (Justinova et al. 2003).

The ability of THC to maintain drug-taking behavior in monkeys without a history of exposure to other drugs shows that this drug possesses reinforcing properties of its own that are not dependent on prior self-administration of other drugs. These findings support the previous conclusion that, under certain experimental conditions, THC has a pronounced abuse liability that is comparable to that of other drugs of abuse (Justinova et al. 2005a). Self-administration of THC by squirrel monkeys provides the most reliable animal model for human marijuana abuse available to date. This animal model now makes it possible to study the relative abuse liability of other natural and synthetic cannabinoids and to preclinically assess new therapeutic strategies for the treatment or prevention of marijuana abuse in humans. 
2.1.2.2 Anandamide and methanandamide: Building on the procedures that were successfully used to obtain THC self-administration in squirrel monkeys, it was shown that that the endocannabinoid anandamide is also self-administered by squirrel monkeys, with or without previous exposure to other drugs (Justinova et al. 2005b). This study also showed that methanandamide, a longer-lasting synthetic analogue of anandamide, can serve as an effective reinforcer of drug-taking behavior when self-administered intravenously by squirrel monkeys. The reinforcing effects of both anandamide and methanandamide in squirrel monkeys appear to be mediated by $\mathrm{CB}_{1}$ receptors, because pre-session treatment with the $\mathrm{CB}_{1}$ antagonist/inverse agonist rimonabant dramatically decreased selfadministration behavior for both cannabinoids. The fact that the endocannabinoid anandamide is self-administered is consistent with the hypothesis that the release of endogenous cannabinoids is involved in brain reward processes and that activation of $\mathrm{CB}_{1}$ receptors by anandamide is part of the signaling of natural rewarding events (Solinas et al. 2007d; Solinas et al. 2008). As discussed below, intravenous self-administration of anandamide by squirrel monkeys provides a procedure for studying the potential abuse liability of medications that activate the endogenous cannabinoid system by interfering with inactivation of endocannabinoids and for investigating mechanisms involved in the reinforcing effects of endocannabinoids.

\subsubsection{Fatty acid amide hydrolase (FAAH) inhibitors and anandamide transport inhibitors}

2.1.2.3.1 URB597: Interest in the development of medications that enhance endocannabinoid signaling in the brain without inducing the psychotropic side-effects associated with systemic administration of direct acting $\mathrm{CB}_{1}$ receptor agonists (like THC) led our laboratory to study the selective FAAH inhibitor URB597, focusing on evaluating its abuse liability and measuring its effects on endocannabinoid levels in the brain. We found (Justinova et al. 2008a; Justinova et al. 2007) that URB597 suppresses FAAH activity and increases anandamide levels in regions of the squirrel monkey brain that participate in motivational, cognitive and emotional functions. This effect is accompanied by a marked decrease in the levels of 2-AG, which would presumably have major effects on endocannabinoid signaling in the brain. This was surprising, because URB597 does not affect activity of the 2-AG-metabolizing enzyme; it may be due to enhanced levels of anandamide causing a compensatory up-regulation in 2-AG mobilization.

We further observed that, over a broad range of experimental conditions, URB597 does not display overt reinforcing properties in monkeys. Indeed, the drug did not have reinforcing effects (i.e., was not self-administered more than vehicle) even when its cumulative intake exceeded by several fold a fully effective dose for FAAH inhibition. Furthermore, neither previous cocaine nor THC exposure predisposed monkeys to self-administer URB597. Indeed, even monkeys that had previously self-administered anandamide at very high rates failed to self-administer the FAAH inhibitor. Finally, URB597 did not alter the reinforcing effects of THC or cocaine, and did not reinstate extinguished drug-seeking behavior in monkeys that had previously self-administered THC or cocaine. These results indicate that the potentiation of endogenous anandamide-mediated transmission produced by URB597 is insufficient per se to produce reinforcing effects. Our findings further imply that FAAH inhibitors such as URB597 - which have demonstrated analgesic, anxiolytic, antidepressant and antihypertensive properties in rodents (Gobbi et al. 2005; Jayamanne et al. 2006; Kathuria et al. 2003) - may be used in humans without anticipated risk of inducing abuse or provoking relapse to drug use in abstinent individuals.

2.1.2.3.2 AM404: Another mechanism by which brain levels of anandamide can be increased is by inhibition of anandamide transport into neurons. The most studied drug of 
this class is AM404, which has been found to exert anxiolytic effects (Bortolato et al. 2006), serve as a reinforcer of intravenous drug-taking behavior in squirrel monkeys, and reinstate extinguished drug-seeking behavior (Justinova and Goldberg 2004). These findings are consistent with the fact that AM404 produces conditioned place preference, an indication of rewarding properties, in rats housed under enriched conditions (Bortolato et al. 2006). On the other hand, place preference does not develop with URB597 under the same conditions (Gobbi et al. 2005). Although both AM404 and URB597 do not have THC-like discriminative or neurochemical effects in rodents (Gobbi et al. 2005; Solinas et al. 2006a; Solinas et al. 2007c), only AM404 has motivational effects in rodents and primates that suggest the potential for abuse.

2.1.3 Second-order schedule and drug seeking-The second-order schedule of drug self-administration (Goldberg et al. 1975; Schindler et al. 2002) has been strongly advocated as an animal model that can be used to focus on drug-seeking behavior, as opposed to drug taking (Arroyo et al. 1998; Everitt and Robbins 2000). This drug-seeking schedule incorporates drug-related stimuli that model the environmental cues that maintain drug seeking and induce drug craving and relapse in humans. Unlike fixed-ratio schedules of drug self-administration, which can only be used to evaluate the ability of a treatment to block the effects of the abused drug after it has been self-administered, second-order schedules can be used to evaluate treatments that target drug seeking, per se, before the abused drug is received. This is important because treatments that reduce drug seeking might provide an especially effective means of achieving and maintaining drug abstinence. In addition to studying the effects of treatments on drug seeking, the second-order schedule can also be used to study relapse induced by drug-related cues, as well as relapse caused by re-exposure to the abused drug or exposure to other drugs. The study by Justinova and colleagues (Justinova et al. 2008b), described in detail below, took advantage of all of these features of a second-order schedule to study the effects of treatments on the maintenance of and relapse to THC seeking.

In the first study utilizing a second-order schedule of THC self-administration (Justinova et al. 2008b), squirrel monkeys' lever-pressing responses intermittently produced brief presentations of a visual stimulus (a colored light). This drug-seeking response produced only the stimulus until the end of the 30-minute session, when the last response of the session produced both the stimulus and intravenous delivery of THC. Monkeys' THCseeking behavior occurred at a high rate even though the drug was not delivered until the end of the session. This behavior depended on both the delivery of THC and the responsecontingent presentations of the drug-paired stimulus. That is, when the brief light stimulus was not presented during the session, THC seeking decreased abruptly and continued to occur at a low rate even when THC was still delivered paired with the stimulus at the end of each session. When both the stimulus and THC delivery were discontinued, responding ceased, but it was immediately reinstated when stimulus presentations were reinstituted. Thus, like re-exposure to the drug, re-exposure to THC-associated stimuli (cues) was a highly effective trigger for relapse following a period of abstinence.

When the THC-seeking procedure was used to evaluate the effects of potential therapeutic treatments, it was found that the $\mathrm{CB}_{1}$ antagonist/inverse agonist, rimonabant, was highly effective in reducing the drug-seeking response. Importantly, treatment with rimonabant produced an immediate decrease in THC seeking, indicating that rimonabant blocked the ability of the stimulus to maintain THC seeking. This finding is consistent with a number of studies showing that rimonabant can reduce the behavioral effects of stimuli associated with other drugs of abuse, including nicotine, alcohol, cocaine, and heroin (Cohen et al. 2005; De Vries and Schoffelmeer 2005; Fattore et al. 2007; Le Foll and Goldberg 2005; Maldonado et al. 2006), as well as the effects of similar cues under second-order food-seeking procedures 
(Evenden and Ko 2007; Thornton-Jones et al. 2005). Thus, this effect of rimonabant on responding maintained by drug-paired cues appears to be a general effect, unlike its ability to reduce drug-taking behavior, which seems to be limited to specific drugs (De Vries and Schoffelmeer 2005). This suggests that the ability to block both drug seeking (behavior reinforced by drug-related cues) and drug taking (behavior reinforced directly by the drug) might make rimonabant and similar drugs especially useful for treating cannabinoid use disorders.

In contrast with rimonabant, treatment with the opioid antagonist, naltrexone, had a more limited effect under the second-order schedule. In another study by Justinova and colleagues (Justinova et al. 2004), naltrexone produced a partial reduction in THC taking under a fixedratio schedule over most of a five-day course of treatment. However, under the second-order schedule, naltrexone only decreased THC seeking during the first two days of treatment. These results might suggest that, like rimonabant, naltrexone can alter both THC seeking and THC taking, but that naltrexone only partially blocks the reinforcing effects of THC. This finding is consistent with the many studies showing functional interactions between the cannabinoid and opioid systems, but it appears that an opioid antagonist alone might not provide significant protection against drug seeking induced by THC-related environmental cues.

During reinstatement testing with the second-order schedule, it was also found that THC seeking was reinstated when the monkeys were passively exposed to THC, anandamide, methanandamide, or the anandamide transport inhibitor AM404. Also consistent with evidence for functional links between the cannabinoid and opioid systems (see section 3 for more details), passive exposure to morphine reinstated THC seeking. Although it has been shown that passive cannabinoid exposure can reinstate cocaine seeking in rats (De Vries et al. 2001; Xi et al. 2006), cocaine did not reinstate THC seeking in the second-order study. This finding is consistent with those of Spano and colleagues (Spano et al. 2004), who found that the cannabinoid agonist, WIN 55,212-2, or heroin, reinstated seeking of WIN 55,212-2 in rats, but cocaine did not.

Rimonabant and naltrexone were tested to determine whether they could block the reinstating effects of passive exposure to THC or morphine. The cannabinoid antagonist/ inverse agonist only blocked the effects of the cannabinoid agonist, and the opioid antagonist only blocked the effects of the opioid agonist. These findings contrast with those of Spano and colleagues (Spano et al. 2004) that rimonabant and the opioid antagonist, naloxone, were both capable of preventing WIN 55,212-2-induced as well as heroin-induced reinstatement of WIN 55,212-2 seeking in rats. This discrepancy could be due to differences between rats and monkeys, or due to differences between THC and WIN 55,212-2, which show different profiles of non-cannabinoid receptor binding.

\subsection{Conditioned place preference and aversion with cannabinoids}

2.2.1 THC and synthetic cannabinoids-An alternative way to assess the rewarding effects of cannabinoids in experimental animals is to study cannabinoid-induced conditioned place preference. Although methodological details differ among laboratories, a typical place conditioning experiment involves differentially pairing a distinct set of environmental (contextual) cues with the effects of a drug. This occurs in a training chamber with two compartments. During the conditioning procedure, the animal receives the drug in one compartment and receives vehicle in the other. These pairings are repeated several times over a number of days. Following conditioning, a choice test is conducted in which a door is opened between the two compartments, and the animal is allowed unrestricted access to both contexts in the absence of the drug. An increase in time spent in the drug-paired context relative to a control value is taken as evidence that the drug has rewarding effects. On the 
other hand, a decrease in time spent in the drug-paired context is taken as evidence that the drug has aversive effects.

Unfortunately, the results of conditioned place preference studies with cannabinoid agonists have ranged from positive place preference to no effect to place aversion. THC, as well as synthetic cannabinoid agonists like CP 55,940 (McGregor et al. 1996), WIN 55,212-2 (Chaperon et al. 1998) and HU 210 (Cheer et al. 2000), can induce conditioned place aversion in rats (Hutcheson et al. 1998; Mallet and Beninger 1998; Parker and Gillies 1995; Sanudo-Pena et al. 1997) and mice (Valjent and Maldonado 2000). THC-induced conditioned place preferences have been reported within limited dose ranges and under restricted experimental conditions in rats and in mice (Braida et al. 2004; Ghozland et al. 2002; Le Foll et al. 2006; Lepore et al. 1995; Valjent and Maldonado 2000). CP 55,940induced conditioned place preference have been reported in rats (Braida et al. 2001a). Interestingly, THC microinjections into the VTA or the shell of the nucleus accumbens can produce conditioned place preference in rats (Zangen et al. 2006). Because of the unresolved inconsistencies in this area of research, it is difficult to draw general conclusions on whether cannabinoids have rewarding or aversive effects in this paradigm.

One explanation for this inconsistency might be that THC's rewarding effects in place conditioning procedures are often masked or reversed by its aversive effects. Differences are reported to exist in the rewarding and aversive effects of cannabinoids in rats and mice in a measure of anxiety. Cannabinoid agonists produced predominantly anxiolytic effects in mice, but predominantly anxiogenic effects in rats (Haller et al. 2007). There also seem to be different mechanisms involved in the THC-induced conditioned place preference compared to aversion. It was found that aversions in mice depend on kappa-opioid receptors (Cheng et al. 2004; Ghozland et al. 2002) and endogenous dynorphin (Zimmer et al. 2001), while preference depends on mu-opioid receptors (Ghozland et al. 2002).

Given the difficulty in obtaining cannabinoid self-administration in rodents, place preference procedures will likely remain a valuable alternative for studying the abuse-related effects of cannabinoid agonists, despite the fact that results have so far been inconsistent. One approach that does not appear to have been attempted is to use cannabinoid-induced place preference to study reinstatement, as has been done with morphine and other drugs (Parker and Mcdonald 2000).

2.2.2 Anandamide-There are only two studies to date that evaluated rewarding or aversive effects of anandamide in a place conditioning procedure. First, Mallet and colleagues (Mallet and Beninger 1998) compared effects of THC and anandamide. Rats in this study received injections of the potent, but non-selective, FAAH inhibitor phenylmethylsulfonyl fluoride (PMSF) prior to anandamide injections in order to prolong its half-life. The study showed that THC, but not anandamide, induced significant conditioned place aversion. Second, Scherma and colleagues (Scherma et al. 2008a) found that anandamide alone had no effects on place conditioning, but it induced conditioned place aversion when its metabolism was inhibited by the selective FAAH inhibitor URB597, which by itself does not produce conditioned place preference or aversion (Gobbi et al. 2005; Kathuria et al. 2003). The latter study by Scherma and colleagues used intravenous catheters for anandamide delivery, while in the former study anandamide was injected intraperitoneally. It is possible that, when injected intraperitoneally, anandamide availability was not sufficient to produce effects in the place preference procedure because of hepatic first-passage metabolism, which does not favor rapid entry of anandamide into the brain. 


\subsection{Discriminative-stimulus effects of cannabinoids}

Drug discrimination is a powerful behavioral assay for discerning similarities and differences among drugs active in the central nervous system (CNS). The subjective and perceptible CNS effects of a compound can be evaluated in this paradigm by training subjects to respond differently when these effects are present versus when they are absent. During drug-discrimination training, the interoceptive effects of a training drug (e.g., THC) are established as a cue for performing a specific operant response (e.g., lever pressing reinforced by food). One of the widely used protocols is the two-lever choice drugdiscrimination procedure. Pressing one lever is reinforced during sessions when the training drug has been injected, and pressing on a second lever is reinforced during sessions when vehicle has been injected. Lever choice during test sessions can be used as an indication of whether a novel drug has effects similar to the training drug, or whether a potential therapeutic alters the effects of the training drug (Solinas et al. 2006b). The range of effects measured by drug discrimination is wider than those of direct measures of reward and reinforcement and can include aversive, anxiogenic or anxiolytic effects (Colpaert 1999).

Discriminative-stimulus effects of $\mathrm{CB}_{1}$ agonists (like $\mathrm{THC}$ ) in animals show a high degree of pharmacological specificity. Generally, only $\mathrm{CB}_{1}$ agonists produce discriminativestimulus effects similar to THC, and only $\mathrm{CB}_{1}$ antagonists block them (Jarbe et al. 2001; Solinas et al. 2004; Solinas et al. 2007c; Wiley et al. 1995b; Wiley et al. 1995a). Among non-cannabinoid drugs, only pentobarbital and diazepam have been found to produce partial generalization to a cannabinoid cue (Barrett et al. 1995; Mokler et al. 1986; Wiley and Martin 1999). The effect of diazepam was not blocked by the $\mathrm{CB}_{1}$ antagonist/inverse agonist rimonabant, suggesting that this effect is mediated by an interaction with the GABAergic system (Wiley and Martin 1999).

Several studies have investigated whether endogenous cannabinoid ligands produce THClike discriminative stimulus effects when they are systemically administered. Anandamide does not generally produce THC-like responding in monkeys and rats in drug-discrimination studies or does so only at very high doses that also dramatically depress rates of responding (Burkey and Nation 1997; Jarbe et al. 2001; Wiley et al. 1998; Wiley et al. 1997). However, metabolically stable, synthetic analogs of anandamide, methanandamide, O-1812 and AM-1346, did induce THC-like responding (Alici and Appel 2004; Burkey and Nation 1997; Jarbe et al. 2006; Wiley et al. 2004). Thus, anandamide's fast metabolic inactivation is likely responsible for its observed weak THC-like discriminative-stimulus effects.

When metabolic inactivation of anandamide via FAAH was blocked by the FAAH inhibitor URB597, anandamide produced dose-related THC-like discriminative-stimulus effects (Solinas et al. 2007c). URB597 alone did not produce any THC-like effects, even at doses several times higher than those that potentiated the effects of anandamide (Gobbi et al. 2005). Another compound interfering with anandamide inactivation, AM404, which is thought to inhibit the transport of anandamide into neurons, produced no THC-like effects itself, but also did not potentiate the THC-like effects of anandamide (Solinas et al. 2007c). These different effects of FAAH blockade and blockade of anandamide transport on THClike discriminative effects of anandamide suggest that membrane transport is not the main mechanism for anandamide inactivation in the brain regions mediating the discriminativestimulus effects of THC. Interestingly, nicotine was shown to produce THC-like discriminative effects after FAAH inhibition with URB597 (Solinas et al. 2007b), which implicates nicotine-induced increases in the release of endocannabinoids in another effect observed in the study, the ability of nicotine to potentiate the discriminative effects of THC. 


\subsection{Tolerance, physical dependence and behavioral sensitization}

2.4.1 Tolerance-The chronic administration of natural or synthetic cannabinoid agonists induces tolerance to most of their pharmacological effects in numerous animal species (Abood and Martin 1992). Tolerance has been shown to develop to the effects of cannabinoids involving antinociception, decreased locomotion, hypothermia and catalepsy, and neuroendocrine effects (Martin 2005), but studies of tolerance to the effects of THC on learning and memory in rats have been contradictory (Delatte et al. 2002; Nava et al. 2001). The development of cannabinoid tolerance is rapid, and a marked decrease of the acute response can sometimes be observed after only the second administration of a cannabinoid agonist (Abood and Martin 1992; Hutcheson et al. 1998). It has been reported that the total number of $\mathrm{CB}_{1}$-binding sites significantly decreases in several brain areas, including the striatum, cortex, limbic system, and cerebellum, during chronic administration of cannabinoids (Rodriguez de Fonseca et al. 1994; Rubino et al. 2000b; Rubino et al. 2000c). Also, there are other cellular adaptations observed in some brain regions, which play an important role in the induction of synaptic plasticity due to cannabinoid chronic exposure, such as increased activation of the cAMP pathway (Rubino et al. 2000b) and adaptations in the ERK cascade (Rubino et al. 2004; Rubino et al. 2005). Together, the downregulation of $\mathrm{CB}_{1}$ receptors along with the changes in these second messenger systems seems to be responsible for the development of cannabinoid tolerance.

Furthermore, there seems to be a relationship between the status of the $\mathrm{CB}_{1}$ receptors and the levels of endocannabinoids. In rats tolerant to THC, there are alterations in endocannabinoid content in various brain regions (Martin 2005). Specifically, anandamide concentrations were increased in the limbic forebrain and decreased in the striatum, midbrain and diencephalon of THC-tolerant rats (Gonzalez et al. 2004). 2-AG concentrations increased in the cerebellum, brainstem and hippocampus, whereas they decreased only in the striatum. It appears that the most consistent findings with a number of centrally acting drugs of abuse is that chronic administration leads to an elevation in endocannabinoid levels in the limbic system (see section 1.3.). This observation is consistent with the notion that endocannabinoids enhance the reinforcing effects of addictive drugs by increasing dopamine release via the inhibition of GABA release in the limbic system (Martin 2005).

Several studies have revealed that cross-tolerance develops for four of the main behavioral/ physiological effects of different exogenous $\mathrm{CB}_{1}$ agonists (analgesia, hypoactivity, catalepsy, and hypothermia) (Pertwee et al. 1993). However, there is not always crosstolerance between anandamide and other cannabinoids. For example, THC and anandamide did not show cross-tolerance to hypothermic effects (Pertwee et al. 1993), but did show cross-tolerance to antinociceptive effects (Welch 1997). Cross-tolerance between opioid and cannabinoid compounds has also been revealed. Morphine and THC elicit cross-tolerance to antinociceptive and hypothermic effects in mice (Thorat and Bhargava 1994). On the other hand, anandamide-tolerant mice were not cross-tolerant to opioids (Welch 1997). Results such as these probably indicate that tolerance to some effects of anandamide involves cannabinoid mechanisms, but tolerance to other effects of anandamide does not.

2.4.2 Physical dependence-Abstinence from cannabis use by chronic users does not produce signs of withdrawal as pronounced as those seen in opioid, ethanol, or barbiturate users. Nonetheless, withdrawal from THC has been reported to induce withdrawal symptoms in both humans (including craving for the drug, decreased appetite, sleep disturbances, anger, aggression (Haney et al. 1999a; Haney et al. 1999b)) and animals (Aceto et al. 1996; Taylor and Fennessy 1982; Verberne et al. 1981). It is likely that the severity of these withdrawal symptoms when use is discontinued is limited by the slow 
release of THC from its depot in fat tissues, where it is stored due to its highly lipophilic nature. This hypothesis is consistent with the fact that administration of the $\mathrm{CB}_{1}$ antagonist/ inverse agonist rimonabant generally precipitates a pronounced withdrawal syndrome in animals that have been chronically treated with cannabinoids (Aceto et al. 1995; Costa et al. 2000; Hutcheson et al. 1998). There are conflicting reports on the ability of rimonabant to precipitate withdrawal signs in rats chronically treated with anandamide, which has a short duration of action (Aceto et al. 1998; Costa et al. 2000).

The behavioral signs of $\mathrm{CB}_{1}$ antagonist-precipitated cannabinoid withdrawal in rodents include increased grooming, wet-dog shakes, a hunched-back posture, piloerection, body tremors, paw tremors and ptosis. The $\mathrm{CB}_{1}$ antagonist/inverse agonist rimonabant failed to precipitate behavioral manifestations of abstinence in $\mathrm{CB}_{1}$ knockout mice given long-term treatment with THC (Ledent et al. 1999), indicating further that somatic signs of abstinence are $\mathrm{CB}_{1}$-receptor mediated. Microinjection of rimonabant into the cerebellum induced severe manifestations of abstinence in mice dependent on WIN 55,212-2 (Castane et al. 2004). When the $\mathrm{CB}_{1}$ antagonist/inverse agonist was administered into the hippocampus and the amygdala, a moderate but significant withdrawal syndrome was also observed. However, no signs of withdrawal were induced when rimonabant was microinjected into the striatum. The cerebellum, and to a lesser extent the hippocampus and the amygdala, participates in the behavioral expression of cannabinoid withdrawal (Castane et al. 2004).

Neurochemical adaptive changes have also been demonstrated during antagonistprecipitated cannabinoid withdrawal in rats and mice, including activation of corticotropin releasing factor (Rodriguez de Fonseca et al. 1997), pronounced increases in the activity of the cAMP pathway in the cerebellum (Hutcheson et al. 1998), and decreases in dopamine transmission in the shell of the nucleus accumbens (Tanda et al. 1999). Some of these signs also occur during withdrawal from other drugs of abuse, such as alcohol (Rossetti et al. 1991), cocaine (Richter et al. 1995) and morphine (Acquas et al. 1991).

Spontaneous cannabinoid withdrawal produced significant time-related alterations in gene transcription (Oliva et al. 2003), such as decreased tyrosine hydroxylase mRNA levels in the ventral tegmental area and increased levels in substantia nigra; increased proenkephalin gene expression in caudate-putamen, nucleus accumbens, olfactory tubercle and piriform cortex; and increased pro-opiomelanocortin gene expression in the arcuate nucleus of the hypothalamus. These alterations induced by spontaneous cannabinoid withdrawal could play a role in the altered vulnerability to other drugs of abuse, as well as in schizoaffective disorders, observed in cannabis users.

2.4.3 Behavioral sensitization-Behavioral sensitization, an increased response to the drug after repeated exposure, is another adaptive neurobiological alteration that occurs after repeated exposure to drugs. The ability to produce this phenomenon is shared by many drugs abused by humans (e.g., opioids, psychostimulants, nicotine and phencyclidine) and has been proposed to play a role in addiction (Robinson and Berridge 1993; Robinson and Berridge 2001), particularly in drug-seeking behavior persisting long after discontinuation of drug use (De Vries et al. 1998). Repeated exposure to cannabinoid agonists can induce behavioral sensitization (Cadoni et al. 2001; Pontieri et al. 2001b), which is typically observed as an increase in behavioral activity in response to a drug challenge given weeks after the last training injection. However, a recent study (Varvel et al. 2007) was not able to replicate THC-induced behavioral sensitization in rodents under various protocols. Crosssensitization may occur between cannabinoid agonists and other drugs abused by humans, including heroin (Pontieri et al. 2001a), morphine (Cadoni et al. 2001) and amphetamine (Lamarque et al. 2001). 
The adaptive neurobiological changes underlying cannabinoid-induced behavioral sensitization are only beginning to be understood. Altered $\mathrm{CB}_{1}$ receptor functionality in the striatum and cerebellum of sensitized rats has been observed, as well as lost responsiveness to cannabinoids by the cAMP pathway in the cerebellum (Rubino et al. 2003). In another study (Cadoni et al. 2008), rats pre-exposed to THC showed behavioral sensitization associated with a reduced stimulation of dopamine transmission in the nucleus accumbens shell and an increased stimulation in the nucleus accumbens core in response to THC challenge. Animals pre-treated with morphine showed behavioral sensitization and differential changes in the dopamine response to a THC challenge, with a decreased response in the shell and an increased response in the core. This suggests that THC-induced behavioral sensitization is associated with changes in the responsiveness of dopamine transmission in the nucleus accumbens subdivisions that are similar to those observed with sensitization induced by other drugs of abuse.

\section{Opioids}

The existence of functional, bidirectional interactions between the endogenous cannabinoid and opioid systems has been demonstrated in numerous studies. Both systems participate in the common circuits involved in the addictive properties of different drugs of abuse. Muopioid and $\mathrm{CB}_{1}$-cannabinoid receptors are both expressed in brain areas involved in reward processes where they share common signaling cascades (Fattore et al. 2005; Maldonado and Rodriguez de Fonseca 2002). The endocannabinoid system is crucial not only for opioidinduced rewarding effects and relapse, but also in the development of physical dependence during chronic opioid administration.

Cross-dependence has been reported between opioid and cannabinoid compounds. In morphine-or methadone-dependent rodents, the opioid antagonist naloxone precipitated a withdrawal syndrome, which was attenuated by THC or anandamide (Hine et al. 1975; Lichtman et al. 2001; Vela et al. 1995). Similarly, morphine decreased withdrawal signs in THC-dependent mice undergoing rimonabant-precipitated withdrawal (Lichtman et al. 2001). Furthermore, rimonabant induced behavioral alterations usually associated with opioid withdrawal when given to morphine-dependent rats, and naloxone induced an opioid withdrawal syndrome when given to animals made cannabinoid-dependent by repeated administration of the potent cannabinoid agonist HU-210 (Navarro et al. 1998). However, long-term treatment with rimonabant reduced the intensity of naloxone-precipitated withdrawal in morphine-tolerant animals (Rubino et al. 2000a). In $\mathrm{CB}_{1}$ knockout mice, the severity of naloxone-precipitated morphine withdrawal was robustly attenuated (Ledent et al. 1999). Reciprocally, the expression of cannabinoid withdrawal was decreased in preproenkephalin knockout mice compared to wild type (Valverde et al. 2000). In contrast, rimonabant-precipitated withdrawal in THC-dependent mice was not affected by deletion of mu, kappa, or delta opioid receptors (Ghozland et al. 2002). Another study (Castane et al. 2003) suggested that cooperative actions of both mu and delta receptors were required for the expression of THC dependence.

Studies of rewarding effects of opioids confirm involvement of the endocannabinoid system. In $\mathrm{CB}_{1}$ knockout mice, morphine did not induce intravenous self-administration (Cossu et al. 2001), but place-conditioning studies show that morphine-induced place preference may or may not develop in these mice dependent on the conditioning paradigm used (Martin et al. 2000; Rice et al. 2002). Rimonabant reduced opioid self-administration and blocked development of heroin-induced conditioned place preference in rodents (De Vries et al. 2003; Navarro et al. 2001). The effects of $\mathrm{CB}_{1}$ antagonist/inverse agonists like rimonabant appear to be relatively weak when the effort required to obtain heroin is low (fixed-ratio 1 schedules), but become more pronounced when the effort is high (progressive-ratio 
schedules) (De Vries et al. 2003; Solinas et al. 2003). Furthermore, $\mathrm{CB}_{1}$ agonists increased the motivation to self-administer heroin under a progressive-ratio schedule (Solinas et al. 2005). On the other hand, opioid antagonists can block cannabinoid-induced place preference or cannabinoid self-administration in rodents and primates (Braida et al. 2001b; Justinova et al. 2004). Deletion of mu-opioid receptors in mice abolished THC place preference, and deletion of kappa-opioid receptors abolished THC place aversion, while unmasking THC place preference (Ghozland et al. 2002). This suggests an opposing activity of mu and kappa-opioid receptors in modulating reward pathways.

The role of the endocannabinoid system in relapse to opioid use has also been established. Blockade of $\mathrm{CB}_{1}$ receptors can prevent heroin-induced reinstatement of heroin-seeking behavior after a long period of extinction, and $\mathrm{CB}_{1}$ agonists can reinstate heroin-seeking behavior in rats (De Vries et al. 2003; Fattore et al. 2003; Solinas et al. 2003). Rimonabant can also block cue-induced heroin seeking in rats (De Vries et al. 2003). On the other hand, heroin reinstated cannabinoid-seeking behavior after a long period of abstinence, and this effect was blocked by rimonabant (Spano et al. 2004). In the same study, naloxone blocked heroin-induced cannabinoid-seeking behavior, which further supports the existence of bidirectional opioid-cannabinoid interactions in the central mechanisms underlying relapse. However, in squirrel monkeys, morphine-induced reinstatement of THC seeking under a second-order schedule was not blocked by rimonabant, and THC-induced reinstatement was not blocked by naltrexone (details in section 2.1.3).

Both opioids' and cannabinoids' rewarding effects are related to their facilitatory effects on mesolimbic dopamine transmission. Heroin or morphine-induced activation of dopamine transmission in the nucleus accumbens does not appear to be mediated by $\mathrm{CB}_{1}$ receptors, because rimonabant does not block this effect (Caille and Parsons 2003; Tanda et al. 1997) and $\mathrm{CB}_{1}$ knockout mice show normal accumbal morphine-induced dopamine elevations (Mascia et al. 1999). Naloxone, on the other hand, prevented the cannabinoid-induced dopamine elevations in the same area (Tanda et al. 1997).

\section{Alcohol}

The endogenous cannabinoid system is involved in both the rewarding effects of alcohol and in relapse to alcohol abuse (Vengeliene et al. 2008). The endocannabinoid system seems to participate in alcohol's rewarding properties by modulating its effects on activation of mesolimbic dopamine transmission. Pharmacological blockade of $\mathrm{CB}_{1}$ receptors blocks dopamine-releasing effects of alcohol, and alcohol did not increase extracellular levels of dopamine in the nucleus accumbens of $\mathrm{CB}_{1}$ knockout mice (Cohen et al. 2002; Hungund et al. 2003). Alcohol acutely inhibits endocannabinoid transmission (Ferrer et al. 2007), which in turn leads to above normal endocannabinoid transmission in reward-related brain areas during chronic alcohol administration, as was revealed by the downregulation of $\mathrm{CB}_{1}$ receptors and by increased levels of anandamide and 2-AG (Hungund and Basavarajappa 2004).

Pharmacological manipulations of the $\mathrm{CB}_{1}$ receptors showed that, generally, $\mathrm{CB}_{1}$ agonists increase (Colombo et al. 2002) and $\mathrm{CB}_{1}$ antagonist/inverse agonists decrease rodents' oral alcohol consumption in self-administration studies (Arnone et al. 1997; Cippitelli et al. 2005). Although $\mathrm{CB}_{1}$ receptor blockade can cause suppression of fluid and food intake (McGregor and Gallate 2004), $\mathrm{CB}_{1}$ antagonist/inverse agonists were still found to decrease alcohol's rewarding effects when this confounding factor was controlled in placeconditioning procedures by giving alcohol intraperitoneally to bypass the oral route of administration (Gessa et al. 2005; Lallemand and De Witte 2006). Moreover, genetic manipulations of the $\mathrm{CB}_{1}$ receptor confirmed that rewarding effects of ethanol require $\mathrm{CB}_{1}$ 
receptor activation, since knockout mice consumed less alcohol in most studies (Crabbe et al. 2006) and did not develop place preference for an alcohol-paired environment (Thanos et al. 2005).

Exposure to the $\mathrm{CB}_{1}$ agonists WIN 55,212-2 or THC promotes relapse to alcohol use in abstinent rats (Lopez-Moreno et al. 2004; McGregor et al. 2005), and the $\mathrm{CB}_{1}$ antagonist/ inverse agonist rimonabant blocks cue-induced relapse to ethanol seeking (Cippitelli et al. 2005). The latter study also showed that in a strain of rats bred for its ethanol preference (alcohol-preferring Marchigian Sardinian - msP rats), there is increased $\mathrm{CB}_{1}$ receptor mRNA expression in brain areas relevant for the processing of reward and rewardassociated behaviors. This suggests that altered function of the $\mathrm{CB}_{1}$ receptor system may be linked to genetic vulnerability to alcohol misuse. In fact, it has recently been reported (Zuo et al. 2007) in a large case-controlled sample that the human $\mathrm{CB}_{1}$ receptor, which is encoded by the CNR1 gene, may play a role in the development of alcoholism.

There is also a question of whether increased anandamide levels in the brain contribute to sustained high levels of alcohol drinking or facilitate relapse to alcohol seeking. Studies in rodents have yielded a spectrum of results so far. One study showed that chronic alcoholinduced increases in extracellular anandamide were due to inhibition of anandamide transport, but not FAAH, in cerebellar granular neurons of mice (Basavarajappa et al. 2003). Blockade of anandamide transport by AM404 in Wistar rats reduced alcohol selfadministration, but did not affect the relapse induced by contextual cues associated with ethanol (Cippitelli et al. 2007). Genetic ablation of FAAH in mice resulted in increased alcohol preference and intake (Blednov et al. 2007). Pharmacological inhibition of FAAH by URB597 produced increased alcohol intake in wild-type mice (Blednov et al. 2007), but had no effect on alcohol intake in Wistar or msP rats (Cippitelli et al. 2008). In the latter study, URB597, like AM404, did not affect relapse to alcohol seeking induced by either cues or stress. The lack of effect of AM404 and URB597 on relapse to alcohol seeking suggests the absence of a primary role of anandamide in the regulation of alcohol-ingestive behaviors in the rat.

\section{Nicotine}

The endocannabinoid system is critically involved in the addictive effects of nicotine. Preclinical evidence clearly implicates $\mathrm{CB}_{1}$ receptors in nicotine addiction, which has led to clinical trials indicating that $\mathrm{CB}_{1}$ receptor antagonists (rimonabant) could be useful as therapeutic agents for smoking cessation (Fernandez and Allison 2004). Rimonabant was shown to block nicotine-induced conditioned place preference, nicotine self-administration, cue-induced reinstatement of nicotine seeking, as well as nicotine-induced dopamine release in the nucleus accumbens shell in rats (Cohen et al. 2002; Cohen et al. 2005; De Vries and Schoffelmeer 2005; Le Foll and Goldberg 2004). CB $_{1}$ knockout mice did not develop nicotine-induced place preference, but they self-administered nicotine similarly to the wild type (Castane et al. 2002; Cossu et al. 2001; Merritt et al. 2008). Genetic deletion or pharmacological inhibition of FAAH by URB597 enhanced the expression of nicotineinduced place preference in mice (Merritt et al. 2008). In contrast, in rats pharmacological inhibition of FAAH by URB597 markedly inhibited the development of nicotine-induced place preference, reduced nicotine-induced reinstatement of drug seeking and reduced nicotine-induced dopamine elevations in the nucleus accumbens shell (Scherma et al. 2008b). Also in rats, inhibition of FAAH by URB597 prevented nicotine-induced activation of dopaminergic neurons in the VTA (Pistis et al. 2008). These results point to drugs that inhibit FAAH as potentially useful agents in the treatment of tobacco dependence in humans 
Interactions between nicotine and the endocannabinoid system may underlie the widespread practice of cannabis and tobacco co-administration in humans. For example, in place conditioning procedures, subthreshold doses of nicotine and THC produced place preference when given in combination (Valjent et al. 2002). Also, nicotine potentiates the discriminative-stimulus effects of low doses of THC, and this effect is mediated in part by the release of anandamide (Solinas et al. 2007b). It was further shown that systemic administration of the $\alpha 7$-nicotinic acetylcholine receptor (nACh) antagonist methyllycaconitine significantly reduced not only the discriminative effects of THC and WIN 55,212-2 and the self-administration of WIN 55,212-2, but also the ability of THC to increase dopamine levels in the nucleus accumbens shell (Solinas et al. 2007a). These findings suggest that drugs that block $\alpha 7 \mathrm{nACh}$ receptors can counteract the addictive properties of THC and may be potentially useful agents in the treatment of cannabis abuse in humans.

\section{Psychostimulants}

The mechanism of action of psychostimulants differs from that of other drugs of abuse. Psychostimulants enhance the activity of dopaminergic neurons by directly acting on the reuptake of monoamines binding to one or multiple monoamine transporters (Rothman and Baumann 2003). There are two primary mechanisms by which psychostimulants affect the dopamine transporter (DAT), but the end result is to inhibit the elimination of dopamine from the synapse and therefore increase the quantity and half-life of synaptic and extrasynaptic dopamine levels (Kalivas 2007). Psychostimulants can be separated into "uptake blockers" (cocaine and methylphenidate) and "releasers" (amphetamines) based on the mechanism of their acute effect on neurotransmitter flux through the DAT. Cocaine binds to DAT, but is not transported into the presynaptic terminal as surrogate dopamine. Amphetamines also bind to DAT, but also translocate into the cell in place of dopamine and enter the dopamine synaptic vesicles. This causes a large buildup of dopamine in the cytosol and reversal of the direction of DAT to release dopamine into the extracellular space. The general separation of drugs into these two classes helps to functionally distinguish the pharmacological profiles of some of the most commonly used psychostimulants. For example, uptake blockers cause little or no persistent dopamine deficits, whereas releasers can cause persistent deficits in monoaminergic neurons (Riddle et al. 2005).

\subsection{Cocaine and methylphenidate}

6.1.1 Cocaine-Results of many preclinical studies indicate that $\mathrm{CB}_{1}$ receptors are not involved in the primary reinforcing effects of cocaine. For example, the ability to selfadminister cocaine was unaffected in $\mathrm{CB}_{1}$ knockout mice, as was development of cocaineinduced place preference (Cossu et al. 2001; Martin et al. 2000). Blockade of $\mathrm{CB}_{1}$ receptors by rimonabant did not interfere with cocaine self-administration in mice, rats or monkeys (De Vries et al. 2001; Lesscher et al. 2005; Tanda et al. 2000). However, there are also contrasting reports, such as the demonstration that rimonabant can affect acquisition of cocaine-induced conditioned place preference (Chaperon et al. 1998). Another report (Soria et al. 2005) showed reduced acquisition of cocaine self-administration in $\mathrm{CB}_{1}$ knockouts and that the maximal effort to obtain cocaine (break-point under a progressive-ratio schedule) was also significantly reduced in $\mathrm{CB}_{1}$ knockout mice or after $\mathrm{CB}_{1}$ receptor blockade in wildtype mice. In the same study, acute cocaine administration induced a similar enhancement in extracellular levels of dopamine in the nucleus accumbens of both $\mathrm{CB}_{1}$ knockout and wildtype mice. This impairment in cocaine self-administration indicates decreased motivation for cocaine-seeking behavior, suggesting a role for $\mathrm{CB}_{1}$ receptors in consolidation of the cocaine addictive process, but not in its acute effects on mesolimbic dopaminergic transmission (Maldonado et al. 2006). 
The endocannabinoid system does appear to be capable of influencing the reinstatement of extinguished cocaine self-administration behavior, since $\mathrm{CB}_{1}$ agonists can induce reinstatement of cocaine seeking (De Vries et al. 2001; Spano et al. 2004) (see section 1.4 for details). Cocaine, on the other hand, does not reinstate extinguished cannabinoid-seeking behavior (Justinova et al. 2008b; Spano et al. 2004). Recent evidence shows that acute cocaine administration could alter synaptic plasticity in the brain reward system (i.e. nucleus accumbens) by abolishing a retrograde long-term depression (LTD) mediated by endocannabinoids (Fourgeaud et al. 2004). Behavioral sensitization to cocaine is accompanied by a decrease in excitatory drive to the nucleus accumbens (Thomas et al. 2001) and a reduction of basal extracellular glutamate in the nucleus accumbens (Pierce et al. 1996). Thus the abolition of endocannabinoid-mediated LTD in the nucleus accumbens of cocaine-exposed animals might serve as a compensatory mechanism to counterbalance the general decrease in glutamatergic activity measured in response to cocaine (Fourgeaud et al. 2004). Although, the endocannabinoid system does not appear to participate in the primary reinforcing effects of cocaine, it is important for maintaining cocaine-seeking behavior, probably by modulating synaptic processes induced by cocaine (Maldonado et al. 2006).

6.1.2 Methylphenidate-Brain dopaminergic and noradrenergic systems play important an role in impulsive behavior, which is manifested at pathological levels in attention-deficit/ hyperactivity disorder (ADHD), for which methylphenidate shows therapeutic efficacy. Impulsivity also plays a crucial role in drug addiction, and prolonged drug intake produces disturbances in inhibition of behavior that might contribute to the compulsivity associated with addiction (Jentsch and Taylor 1999). This hypothesis, that drug addiction and impulsivity are strongly interrelated, has been supported by several recent studies in both humans and laboratory animals demonstrating that elevated impulsivity might predispose individuals to initiate or maintain drug seeking and taking (Pattij and Vanderschuren 2008).

The endocannabinoid system, and particularly $\mathrm{CB}_{1}$ receptors, has been implicated in higher cognitive functions including attention. In healthy volunteers, marijuana and THC have been demonstrated to increase the occurrence of risk-taking behavior in the laboratory and induce impulsive action in a stop signal task, but not delay aversion (McDonald et al. 2003; Ramaekers et al. 2006), which suggests a role for the cannabinoid system in impulsivity. A recent study provided evidence for a differential involvement of the endocannabinoid system in independent measures of impulsivity, as the $\mathrm{CB}_{1}$ antagonist/inverse agonist rimonabant primarily affected inhibitory control, and did not affect either impulsive choice nor response inhibition, whereas the $\mathrm{CB}_{1}$ agonist WIN 55,212-2 only slightly affected response inhibition (Pattij et al. 2007).

\subsection{Amphetamine, methamphetamine and 3,4-methylendioxymethamphetamine (MDMA)}

Dopamine-endocannabinoid interactions have been suggested to be important for the development of amphetamine-induced behavioral sensitization. Anandamide and 2-AG are differentially modulated by dopamine, via activation of $\mathrm{D}_{1}$ and $\mathrm{D}_{2}$ receptors (Patel et al. 2003), which play a significant role in the induction and expression of amphetamine sensitization. Repeated exposure to THC can induce behavioral sensitization not only to cannabinoids, but also to psychostimulants, including amphetamine (Gorriti et al. 1999; Lamarque et al. 2001). In line with this finding is the report that $\mathrm{CB}_{1}$ knockout mice failed to sensitize to the locomotor stimulant effects of amphetamine (Thiemann et al. 2008). Furthermore, amphetamine-sensitized wild-type animals in that study had decreased levels of anandamide and 2-AG in the ventral striatum (which contains the nucleus accumbens). It seems that amphetamine, which directly increases dopamine activity, can trigger a compensatory reduction in cannabinoid levels, most likely via trans-synaptic mechanisms 
within mesolimbic circuitry (van der Stelt and Di Marzo 2003)). However, amphetamine also releases endocannabinoids in rat amygdala, producing LTD by a dopamine-independent mechanism mediated by $\mathrm{CB}_{1}$ receptors (Huang et al. 2003), and these endocannabinoids participate in the synaptic plasticity produced by amphetamine in mesocorticolimbic structures (Wolf et al. 2004).

Studies investigating involvement of the endocannabinoid system in the reinforcing effects of amphetamines show conflicting results. Amphetamine is self-administered in $\mathrm{CB}_{1}$ knockout mice (Cossu et al. 2001). On the other hand, the $\mathrm{CB}_{1}$ antagonist/inverse agonist AM251 decreased and anandamide and methanandamide increased methamphetamine selfadministration under a fixed-ratio schedule in rats (Vinklerova et al. 2002). Rimonabant was also shown to block methamphetamine- and cue-induced reinstatement of methamphetamine-seeking behavior in rats (Anggadiredja et al. 2004). Studies with MDMA showed contradictory effects as well. Blockade of $\mathrm{CB}_{1}$ receptors antagonized MDMAinduced place preference (Braida et al. 2005), but increased intracerebroventricular selfadministration of MDMA (Braida et al. 2004). The increase in operant responding induced by rimonabant indicates a decreased motivation to self-administer amphetamine and its derivatives, suggesting that the endocannabinoid system influences the mechanisms regulating MDMA's reinforcing effects (Sala and Braida 2005).

It is important to note that, as with alcohol, marijuana, and heroin, a human genetic variant of the cannabinoid $\mathrm{CB}_{1}$ receptor gene $\mathrm{CNR} 1$ has been associated with susceptibility to cocaine and amphetamine dependence (Ballon et al. 2006; Comings et al. 1997; Zhang et al. 2004).

\section{Endocannabinoid system and treatment of drug addiction}

As can be seen by the large number of studies in this area in recent years, the role of the endocannabinoid system in drug abuse and addiction is the focus of intense activity. This interest is generated for several important reasons. Endocannabinoids appear to modulate the direct reinforcing effects of many drugs, the ability of these drugs to induce relapse, and perhaps most interestingly, the ability of drug-related cues to induce relapse. The abuse of cannabis itself is a widespread phenomenon, and large numbers of people seek treatment for cannabis dependence each year. Cannabinoid antagonists represent a unique approach to the treatment of substance abuse (including obesity and addiction to both licit and illicit drugs). Along with replacement therapy (e.g., methadone, nicotine replacement), aversion therapy (e.g., Antabuse), and antagonist or mixed agonist therapies that are specific for opioid addiction (e.g., naltrexone and buprenorphine, respectively), manipulations of the endocannabinoid system offer one of the very few kinds of pharmacotherapeutic treatments that has shown promise for treating addiction. Among these treatments, cannabinoid-based therapies may be the only ones with the potential to target addiction and relapse, per se, as opposed to targeting the abuse of a single substance. Unfortunately, the recent rejection of the $\mathrm{CB}_{1}$ antagonist/inverse agonist rimonabant as an aid in smoking cessation by the FDA indicates that the search for a cannabinoid-related treatment for addiction is just beginning. Recently developed neutral antagonists that in animals appear to lack the unwanted side effects of $\mathrm{CB}_{1}$ antagonist/inverse agonists such as rimonabant (details in section 1.4.), as well as drugs such as FAAH inhibitors that alter endocannabinoid signaling, are two examples of potentially useful approaches to cannabinoid-related treatment of addiction. As our understanding of the endocannabinoid system rapidly increases, it is hoped that the promise of safe and effective therapies based on this system will soon be realized. 


\section{Acknowledgments}

The preparation of this manuscript was supported in part by the Intramural Research Program of the National Institute on Drug Abuse, National Institutes of Health, Department of Health and Human Services and Maryland Psychiatric Research Center, Department of Psychiatry, University of Maryland School of Medicine, Baltimore, Maryland.

\section{References}

1. Abood ME, Martin BR. Neurobiology of marijuana abuse. Trends Pharmacol Sci 1992;13:201-206. [PubMed: 1604713]

2. Aceto MD, Scates SM, Lowe JA, et al. Dependence on delta 9-tetrahydrocannabinol: studies on precipitated and abrupt withdrawal. J Pharmacol Exp Ther 1996;278:1290-1295. [PubMed: 8819514]

3. Aceto MD, Scates SM, Lowe JA, et al. Cannabinoid precipitated withdrawal by the selective cannabinoid receptor antagonist, SR 141716A. Eur J Pharmacol 1995;282:R1-R2. [PubMed: 7498260]

4. Aceto MD, Scates SM, Razdan RK, et al. Anandamide, an endogenous cannabinoid, has a very low physical dependence potential. J Pharmacol Exp Ther 1998;287:598-605. [PubMed: 9808686]

5. Acquas E, Carboni E, Di Chiara G. Profound depression of mesolimbic dopamine release after morphine withdrawal in dependent rats. Eur J Pharmacol 1991;193:133-134. [PubMed: 1646728]

6. Agurell S, Halldin M, Lindgren JE, et al. Pharmacokinetics and metabolism of delta 1tetrahydrocannabinol and other cannabinoids with emphasis on man. Pharmacol Rev 1986;38:2143. [PubMed: 3012605]

7. Alici T, Appel JB. Increasing the selectivity of the discriminative stimulus effects of delta 9tetrahydrocannabinol: complete substitution with methanandamide. Pharmacol Biochem Behav 2004;79:431-437. [PubMed: 15582014]

8. American Psychiatric Association. DSM-IV: Diagnostic and statistical manual of mental disorders. Fourth. APA; Washington DC: 1994.

9. Anggadiredja K, Nakamichi M, Hiranita T, et al. Endocannabinoid system modulates relapse to methamphetamine seeking: possible mediation by the arachidonic acid cascade. Neuropsychopharmacology 2004;29:1470-1478. [PubMed: 15085091]

10. Arnold JM, Roberts DC. A critique of fixed and progressive ratio schedules used to examine the neural substrates of drug reinforcement. Pharmacol Biochem Behav 1997;57:441-447. [PubMed: 9218268]

11. Arnone M, Maruani J, Chaperon F, et al. Selective inhibition of sucrose and ethanol intake by SR 141716, an antagonist of central cannabinoid (CB1) receptors. Psychopharmacology (Berl) 1997;132:104-106. [PubMed: 9272766]

12. Arroyo M, Markou A, Robbins TW, et al. Acquisition, maintenance and reinstatement of intravenous cocaine self-administration under a second-order schedule of reinforcement in rats: effects of conditioned cues and continuous access to cocaine. Psychopharmacology (Berl) 1998;140:331-344. [PubMed: 9877013]

13. Ballon N, Leroy S, Roy C, et al. (AAT)n repeat in the cannabinoid receptor gene (CNR1): association with cocaine addiction in an African-Caribbean population. Pharmacogenomics $\mathrm{J}$ 2006;6:126-130. [PubMed: 16314880]

14. Barrett RL, Wiley JL, Balster RL, et al. Pharmacological specificity of delta 9tetrahydrocannabinol discrimination in rats. Psychopharmacology (Berl) 1995;118:419-424. [PubMed: 7568628]

15. Basavarajappa BS, Saito M, Cooper TB, et al. Chronic ethanol inhibits the anandamide transport and increases extracellular anandamide levels in cerebellar granule neurons. Eur J Pharmacol 2003;466:73-83. [PubMed: 12679143]

16. Bazinet RP, Lee HJ, Felder CC, et al. Rapid high-energy microwave fixation is required to determine the anandamide ( $\mathrm{N}$-arachidonoylethanolamine) concentration of rat brain. Neurochem Res 2005;30:597-601. [PubMed: 16176062] 
17. Bequet F, Uzabiaga F, Desbazeille M, et al. CB1 receptor-mediated control of the release of endocannabinoids (as assessed by microdialysis coupled with LC/MS) in the rat hypothalamus. Eur J Neurosci 2007;26:3458-3464. [PubMed: 18052990]

18. Bergman J, Johanson CE. The reinforcing properties of diazepam under several conditions in the rhesus monkey. Psychopharmacology (Berl) 1985;86:108-113. [PubMed: 3927346]

19. Blednov YA, Cravatt BF, Boehm SL, et al. Role of endocannabinoids in alcohol consumption and intoxication: studies of mice lacking fatty acid amide hydrolase. Neuropsychopharmacology 2007;32:1570-1582. [PubMed: 17164820]

20. Bortolato M, Campolongo P, Mangieri RA, et al. Anxiolytic-like properties of the anandamide transport inhibitor AM404. Neuropsychopharmacology 2006;31:2652-2659. [PubMed: 16541083]

21. Braida D, Iosue S, Pegorini S, et al. Delta9-tetrahydrocannabinol-induced conditioned place preference and intracerebroventricular self-administration in rats. Eur J Pharmacol 2004;506:6369. [PubMed: 15588625]

22. Braida D, Iosue S, Pegorini S, et al. 3,4 Methylenedioxymethamphetamine-induced conditioned place preference (CPP) is mediated by endocannabinoid system. Pharmacol Res 2005;51:177-182. [PubMed: 15629265]

23. Braida D, Pozzi M, Cavallini R, et al. Conditioned place preference induced by the cannabinoid agonist CP 55,940: interaction with the opioid system. Neuroscience 2001a;104:923-926. [PubMed: 11457579]

24. Braida D, Pozzi M, Parolaro D, et al. Intracerebral self-administration of the cannabinoid receptor agonist CP 55,940 in the rat: interaction with the opioid system. Eur J Pharmacol 2001b;413:227234. [PubMed: 11226397]

25. Branch MN, Dearing ME, Lee DM. Acute and chronic effects of delta 9-tetrahydrocannabinol on complex behavior of squirrel monkeys. Psychopharmacology (Berl) 1980;71:247-256. [PubMed: 6256795]

26. Brodie MS, Pesold C, Appel SB. Ethanol directly excites dopaminergic ventral tegmental area reward neurons. Alcohol Clin Exp Res 1999;23:1848-1852. [PubMed: 10591603]

27. Burkey RT, Nation JR. (R)-methanandamide, but not anandamide, substitutes for delta 9-THC in a drug-discrimination procedure. Exp Clin Psychopharmacol 1997;5:195-202. [PubMed: 9260067]

28. Cadoni C, Pisanu A, Solinas M, et al. Behavioural sensitization after repeated exposure to Delta 9tetrahydrocannabinol and cross-sensitization with morphine. Psychopharmacology (Berl) 2001;158:259-266. [PubMed: 11713615]

29. Cadoni C, Valentini V, Di Chiara G. Behavioral sensitization to Delta(9)-tetrahydrocannabinol and cross-sensitization with morphine: differential changes in accumbal shell and core dopamine transmission. J Neurochem 2008;106(4):1586-93. [PubMed: 18513369]

30. Caille S, Parsons LH. SR141716A reduces the reinforcing properties of heroin but not heroininduced increases in nucleus accumbens dopamine in rats. Eur J Neurosci 2003;18:3145-3149. [PubMed: 14656311]

31. Caille S, varez-Jaimes L, Polis I, et al. Specific alterations of extracellular endocannabinoid levels in the nucleus accumbens by ethanol, heroin, and cocaine self-administration. J Neurosci 2007;27:3695-3702. [PubMed: 17409233]

32. Cami J, Farre M. Drug addiction. N Engl J Med 2003;349:975-986. [PubMed: 12954747]

33. Carroll, ME.; Meisch, RA. Increased drug-reinforced behavior due to food deprivation. In: Thompson, T.; Dews, PB.; Barrett, JE., editors. Advances in Behavioral Pharmacology. Academic Press; New York: 1984. p. 47-88.

34. Castane A, Maldonado R, Valverde O. Role of different brain structures in the behavioural expression of WIN 55,212-2 withdrawal in mice. Br J Pharmacol 2004;142:1309-1317. [PubMed: 15265804]

35. Castane A, Robledo P, Matifas A, et al. Cannabinoid withdrawal syndrome is reduced in double mu and delta opioid receptor knockout mice. Eur J Neurosci 2003;17:155-159. [PubMed: 12534979]

36. Castane A, Valjent E, Ledent $\mathrm{C}$, et al. Lack of CB1 cannabinoid receptors modifies nicotine behavioural responses, but not nicotine abstinence. Neuropharmacology 2002;43:857-867. [PubMed: 12384171] 
37. CEWG. Proceedings of the Community Epidemiology Work Group Highlights and Executive Summary. National Institute on Drug Abuse; Bethesda, MD: 2007. Epidemiologic Trends in Drug Abuse. NIH Publication No 07-6200

38. Chaperon F, Soubrie P, Puech AJ, et al. Involvement of central cannabinoid (CB1) receptors in the establishment of place conditioning in rats. Psychopharmacology (Berl) 1998;135:324-332. [PubMed: 9539255]

39. Chaperon F, Thiebot MH. Behavioral effects of cannabinoid agents in animals. Crit Rev Neurobiol 1999;13:243-281. [PubMed: 10803637]

40. Cheer JF, Kendall DA, Marsden CA. Cannabinoid receptors and reward in the rat: a conditioned place preference study. Psychopharmacology (Berl) 2000;151:25-30. [PubMed: 10958113]

41. Chen JP, Paredes W, Li J, et al. Delta 9-tetrahydrocannabinol produces naloxone-blockable enhancement of presynaptic basal dopamine efflux in nucleus accumbens of conscious, freelymoving rats as measured by intracerebral microdialysis. Psychopharmacology (Berl) 1990;102:156-162. [PubMed: 2177204]

42. Cheng HY, Laviolette SR, van der Kooy D, et al. DREAM ablation selectively alters THC place aversion and analgesia but leaves intact the motivational and analgesic effects of morphine. Eur $\mathbf{J}$ Neurosci 2004;19:3033-3041. [PubMed: 15182311]

43. Cippitelli A, Bilbao A, Gorriti MA, et al. The anandamide transport inhibitor AM404 reduces ethanol self-administration. Eur J Neurosci 2007;26:476-486. [PubMed: 17650118]

44. Cippitelli A, Bilbao A, Hansson AC, et al. Cannabinoid CB1 receptor antagonism reduces conditioned reinstatement of ethanol-seeking behavior in rats. Eur J Neurosci 2005;21:2243-2251. [PubMed: 15869521]

45. Cippitelli A, Cannella N, Braconi S, et al. Increase of brain endocannabinoid anandamide levels by FAAH inhibition and alcohol abuse behaviours in the rat. Psychopharmacology (Berl) 2008;198:449-460. [PubMed: 18446329]

46. Cohen C, Kodas E, Griebel G. CB1 receptor antagonists for the treatment of nicotine addiction. Pharmacol Biochem Behav 2005;81:387-395. [PubMed: 15935455]

47. Cohen C, Perrault G, Voltz C, et al. SR141716, a central cannabinoid (CB(1)) receptor antagonist, blocks the motivational and dopamine-releasing effects of nicotine in rats. Behav Pharmacol 2002;13:451-463. [PubMed: 12394421]

48. Collins RJ, Weeks JR, Cooper MM, et al. Prediction of abuse liability of drugs using IV selfadministration by rats. Psychopharmacology (Berl) 1984;82:6-13. [PubMed: 6141585]

49. Colombo G, Serra S, Brunetti G, et al. Stimulation of voluntary ethanol intake by cannabinoid receptor agonists in ethanol-preferring sP rats. Psychopharmacology (Berl) 2002;159:181-187. [PubMed: 11862347]

50. Colpaert FC. Drug discrimination in neurobiology. Pharmacol Biochem Behav 1999;64:337-345. [PubMed: 10515310]

51. Comings DE, Muhleman D, Gade R, et al. Cannabinoid receptor gene (CNR1): association with i.v. drug use. Mol Psychiatry 1997;2:161-168. [PubMed: 9106242]

52. Cossu G, Ledent C, Fattore L, et al. Cannabinoid CB1 receptor knockout mice fail to selfadminister morphine but not other drugs of abuse. Behav Brain Res 2001;118:61-65. [PubMed: 11163634]

53. Costa B, Giagnoni G, Colleoni M. Precipitated and spontaneous withdrawal in rats tolerant to anandamide. Psychopharmacology (Berl) 2000;149:121-128. [PubMed: 10805606]

54. Crabbe JC, Phillips TJ, Harris RA, et al. Alcohol-related genes: contributions from studies with genetically engineered mice. Addict Biol 2006;11:195-269. [PubMed: 16961758]

55. De Vries TJ, Homberg JR, Binnekade R, et al. Cannabinoid modulation of the reinforcing and motivational properties of heroin and heroin-associated cues in rats. Psychopharmacology (Berl) 2003;168:164-169. [PubMed: 12669182]

56. De Vries TJ, Schoffelmeer AN. Cannabinoid CB1 receptors control conditioned drug seeking. Trends Pharmacol Sci 2005;26:420-426. [PubMed: 15992935]

57. De Vries TJ, Schoffelmeer AN, Binnekade R, et al. Drug-induced reinstatement of heroin- and cocaine-seeking behaviour following long-term extinction is associated with expression of behavioural sensitization. Eur J Neurosci 1998;10:3565-3571. [PubMed: 9824469] 
58. De Vries TJ, Shaham Y, Homberg JR, et al. A cannabinoid mechanism in relapse to cocaine seeking. Nat Med 2001;7:1151-1154. [PubMed: 11590440]

59. Delatte MS, Winsauer PJ, Moerschbaecher JM. Tolerance to the disruptive effects of Delta(9)THC on learning in rats. Pharmacol Biochem Behav 2002;74:129-140. [PubMed: 12376160]

60. Dewey WL. Cannabinoid pharmacology. Pharmacol Rev 1986;38:151-178. [PubMed: 3529128]

61. Di Chiara G, Tanda G, Bassareo V, et al. Drug addiction as a disorder of associative learning. Role of nucleus accumbens shell/extended amygdala dopamine. Ann N Y Acad Sci 1999;877:461-485. [PubMed: 10415665]

62. Di Marzo V, Berrendero F, Bisogno T, et al. Enhancement of anandamide formation in the limbic forebrain and reduction of endocannabinoid contents in the striatum of delta9tetrahydrocannabinol-tolerant rats. J Neurochem 2000;74:1627-1635. [PubMed: 10737621]

63. Evenden J, Ko T. The effects of anorexic drugs on free-fed rats responding under a second-order FI15-min (FR10:S) schedule for high incentive foods. Behav Pharmacol 2007;18:61-69. [PubMed: 17218798]

64. Everitt BJ, Robbins TW. Second-order schedules of drug reinforcement in rats and monkeys: measurement of reinforcing efficacy and drug-seeking behaviour. Psychopharmacology (Berl) 2000;153:17-30. [PubMed: 11255926]

65. Fattore L, Cossu G, Martellotta CM, et al. Intravenous self-administration of the cannabinoid CB1 receptor agonist WIN 55,212-2 in rats. Psychopharmacology (Berl) 2001;156:410-416. [PubMed: 11498718]

66. Fattore L, Deiana S, Spano SM, et al. Endocannabinoid system and opioid addiction: behavioural aspects. Pharmacol Biochem Behav 2005;81:343-359. [PubMed: 15935459]

67. Fattore L, Fadda P, Fratta W. Endocannabinoid regulation of relapse mechanisms. Pharmacol Res 2007;56:418-427. [PubMed: 17936008]

68. Fattore L, Spano MS, Cossu G, et al. Cannabinoid mechanism in reinstatement of heroin-seeking after a long period of abstinence in rats. Eur J Neurosci 2003;17:1723-1726. [PubMed: 12752390]

69. Fernandez JR, Allison DB. Rimonabant Sanofi-Synthelabo. Curr Opin Investig Drugs 2004;5:430435.

70. Ferrer B, Bermudez-Silva FJ, Bilbao A, et al. Regulation of brain anandamide by acute administration of ethanol. Biochem J 2007;404:97-104. [PubMed: 17302558]

71. Fourgeaud L, Mato S, Bouchet D, et al. A single in vivo exposure to cocaine abolishes endocannabinoid-mediated long-term depression in the nucleus accumbens. J Neurosci 2004;24:6939-6945. [PubMed: 15295029]

72. Fusco FR, Martorana A, Giampa C, et al. Immunolocalization of CB1 receptor in rat striatal neurons: a confocal microscopy study. Synapse 2004;53:159-167. [PubMed: 15236348]

73. Gessa GL, Serra S, Vacca G, et al. Suppressing effect of the cannabinoid CB1 receptor antagonist, SR147778, on alcohol intake and motivational properties of alcohol in alcohol-preferring sP rats. Alcohol Alcohol 2005;40:46-53. [PubMed: 15582988]

74. Ghozland S, Matthes HW, Simonin F, et al. Motivational effects of cannabinoids are mediated by mu-opioid and kappa-opioid receptors. J Neurosci 2002;22:1146-1154. [PubMed: 11826143]

75. Giuffrida A, Parsons LH, Kerr TM, et al. Dopamine activation of endogenous cannabinoid signaling in dorsal striatum. Nat Neurosci 1999;2:358-363. [PubMed: 10204543]

76. Gobbi G, Bambico FR, Mangieri R, et al. Antidepressant-like activity and modulation of brain monoaminergic transmission by blockade of anandamide hydrolysis. Proc Natl Acad Sci U S A 2005;102:18620-18625. [PubMed: 16352709]

77. Goldberg SR, Hoffmeister F, Schlichting UU, et al. A comparison of pentobarbital and cocaine self-administration in rhesus monkeys: effects of dose and fixed-ratio parameter. J Pharmacol Exp Ther 1971;179:277-283. [PubMed: 5002482]

78. Goldberg SR, Kelleher RT, Morse WH. Second-order schedules of drug injection. Fed Proc 1975;34:1771-1776. [PubMed: 1149889]

79. Goldberg SR, Spealman RD, Goldberg DM. Persistent behavior at high rates maintained by intravenous self-administration of nicotine. Science 1981;214:573-575. [PubMed: 7291998] 
80. Gonzalez S, Cascio MG, Fernandez-Ruiz J, et al. Changes in endocannabinoid contents in the brain of rats chronically exposed to nicotine, ethanol or cocaine. Brain Res 2002;954:73-81. [PubMed: 12393235]

81. Gonzalez S, Fernandez-Ruiz J, Di Marzo V, et al. Behavioral and molecular changes elicited by acute administration of SR141716 to Delta9-tetrahydrocannabinol-tolerant rats: an experimental model of cannabinoid abstinence. Drug Alcohol Depend 2004;74:159-170. [PubMed: 15099659]

82. Gonzalez S, Schmid PC, Fernandez-Ruiz J, et al. Region-dependent changes in endocannabinoid transmission in the brain of morphine-dependent rats. Addict Biol 2003;8:159-166. [PubMed: 12850774]

83. Gorriti MA, Rodriguez de FF, Navarro M, et al. Chronic (-)-delta9-tetrahydrocannabinol treatment induces sensitization to the psychomotor effects of amphetamine in rats. Eur J Pharmacol 1999;365:133-142. [PubMed: 9988095]

84. Haller J, Matyas F, Soproni K, et al. Correlated species differences in the effects of cannabinoid ligands on anxiety and on GABAergic and glutamatergic synaptic transmission. Eur J Neurosci 2007;25:2445-2456. [PubMed: 17445240]

85. Haney M, Comer SD, Ward AS, et al. Factors influencing marijuana self-administration by humans. Behav Pharmacol 1997;8:101-112. [PubMed: 9833006]

86. Haney M, Ward AS, Comer SD, et al. Abstinence symptoms following oral THC administration to humans. Psychopharmacology (Berl) 1999a;141:385-394. [PubMed: 10090646]

87. Haney M, Ward AS, Comer SD, et al. Abstinence symptoms following smoked marijuana in humans. Psychopharmacology (Berl) 1999b;141:395-404. [PubMed: 10090647]

88. Harris RT, Waters W, McLendon D. Evaluation of reinforcing capability of delta-9tetrahydrocannabinol in rhesus monkeys. Psychopharmacologia 1974;37:23-29. [PubMed: 4413316]

89. Hine B, Torrelio M, Gershon S. Attenuation of precipitated abstinence in methadone-dependent rats by delta 9-THC. Psychopharmacol Commun 1975;1:275-283. [PubMed: 1241452]

90. Hodos W. Progressive ratio as a measure of reward strength. Science 1961;134:943-944. [PubMed: 13714876]

91. Hohmann AG, Herkenham M. Localization of cannabinoid CB(1) receptor mRNA in neuronal subpopulations of rat striatum: a double-label in situ hybridization study. Synapse 2000;37:71-80. [PubMed: 10842353]

92. Hollister LE. Health aspects of cannabis. Pharmacol Rev 1986;38:1-20. [PubMed: 3520605]

93. Huang YC, Wang SJ, Chiou LC, et al. Mediation of amphetamine-induced long-term depression of synaptic transmission by CB1 cannabinoid receptors in the rat amygdala. J Neurosci 2003;23:10311-10320. [PubMed: 14614090]

94. Huestis MA, Gorelick DA, Heishman SJ, et al. Blockade of effects of smoked marijuana by the CB1-selective cannabinoid receptor antagonist SR141716. Arch Gen Psychiatry 2001;58:322-328. [PubMed: 11296091]

95. Hungund BL, Basavarajappa BS. Role of endocannabinoids and cannabinoid CB1 receptors in alcohol-related behaviors. Ann N Y Acad Sci 2004;1025:515-527. [PubMed: 15542757]

96. Hungund BL, Szakall I, Adam A, et al. Cannabinoid CB1 receptor knockout mice exhibit markedly reduced voluntary alcohol consumption and lack alcohol-induced dopamine release in the nucleus accumbens. J Neurochem 2003;84:698-704. [PubMed: 12562514]

97. Hutcheson DM, Tzavara ET, Smadja C, et al. Behavioural and biochemical evidence for signs of abstinence in mice chronically treated with delta-9-tetrahydrocannabinol. Br J Pharmacol 1998;125:1567-1577. [PubMed: 9884086]

98. Jacobs EH, Smit AB, De Vries TJ, et al. Neuroadaptive effects of active versus passive drug administration in addiction research. Trends Pharmacol Sci 2003;24:566-573. [PubMed: 14607079]

99. Jarbe TU, Lamb RJ, Lin S, et al. (R)-methanandamide and Delta 9-THC as discriminative stimuli in rats: tests with the cannabinoid antagonist SR-141716 and the endogenous ligand anandamide. Psychopharmacology (Berl) 2001;156:369-380. [PubMed: 11498713] 
100. Jarbe TU, Lamb RJ, Liu Q, et al. Discriminative stimulus functions of AM-1346, a CB1R selective anandamide analog in rats trained with Delta9-THC or (R)-methanandamide (AM-356). Psychopharmacology (Berl) 2006;188:315-323. [PubMed: 16953384]

101. Jayamanne A, Greenwood R, Mitchell VA, et al. Actions of the FAAH inhibitor URB597 in neuropathic and inflammatory chronic pain models. Br J Pharmacol 2006;147:281-288. [PubMed: 16331291]

102. Jentsch JD, Taylor JR. Impulsivity resulting from frontostriatal dysfunction in drug abuse: implications for the control of behavior by reward-related stimuli. Psychopharmacology (Berl) 1999;146:373-390. [PubMed: 10550488]

103. Johanson CE, Balster RL. A summary of the results of a drug self-administration study using substitution procedures in rhesus monkeys. Bull Narc 1978;30:43-54. [PubMed: 36945]

104. Justinova Z, Bortolato M, Mangieri RA, et al. Lack of abuse liability of the FAAH inhibitor URB597 in squirrel monkeys. FASEB J 2007;21:A409.

105. Justinova, Z.; Goldberg, SR. The abuse potential of the endocannabinoid transport inhibitor AM404: Self-administration by squirrel monkeys. 2005 Symposium on the Cannabinoids; Burlington, Vermont. 2004. p. 176

106. Justinova Z, Goldberg SR, Heishman SJ, et al. Self-administration of cannabinoids by experimental animals and human marijuana smokers. Pharmacol Biochem Behav 2005a;81:285299. [PubMed: 15932767]

107. Justinova Z, Mangieri RA, Bortolato M, et al. Fatty acid amide hydrolase inhibition heightens anandamide signaling without producing reinforcing effects in primates. Biol Psychiatry 2008a; 64(11):930-7. [PubMed: 18814866]

108. Justinova Z, Munzar P, Panlilio LV, et al. Blockade of THC-Seeking Behavior and Relapse in Monkeys by the Cannabinoid CB(1)-Receptor Antagonist Rimonabant. Neuropsychopharmacology 2008b;33:2870-7. [PubMed: 18305459]

109. Justinova Z, Solinas M, Tanda G, et al. The endogenous cannabinoid anandamide and its synthetic analog $\mathrm{R}(+)$-methanandamide are intravenously self-administered by squirrel monkeys. J Neurosci 2005b;25:5645-5650. [PubMed: 15944392]

110. Justinova Z, Tanda G, Munzar P, et al. The opioid antagonist naltrexone reduces the reinforcing effects of Delta 9 tetrahydrocannabinol (THC) in squirrel monkeys. Psychopharmacology (Berl) 2004;173:186-194. [PubMed: 14668977]

111. Justinova Z, Tanda G, Redhi GH, et al. Self-administration of Delta(9)-tetrahydrocannabinol (THC) by drug naive squirrel monkeys. Psychopharmacology (Berl) 2003;169:135-140. [PubMed: 12827345]

112. Kalivas PW. Cocaine and amphetamine-like psychostimulants: neurocircuitry and glutamate neuroplasticity. Dialogues Clin Neurosci 2007;9:389-397. [PubMed: 18286799]

113. Kathuria S, Gaetani S, Fegley D, et al. Modulation of anxiety through blockade of anandamide hydrolysis. Nat Med 2003;9:76-81. [PubMed: 12461523]

114. Kauer JA. Learning mechanisms in addiction: synaptic plasticity in the ventral tegmental area as a result of exposure to drugs of abuse. Annu Rev Physiol 2004;66:447-475. [PubMed: 14977410]

115. Kaymakcalan S. Tolerance to and dependence on cannabis. Bull Narc 1973;25:39-47.

116. Kofalvi A, Rodrigues RJ, Ledent C, et al. Involvement of cannabinoid receptors in the regulation of neurotransmitter release in the rodent striatum: a combined immunochemical and pharmacological analysis. J Neurosci 2005;25:2874-2884. [PubMed: 15772347]

117. Koob GF. Drugs of abuse: anatomy, pharmacology and function of reward pathways. Trends Pharmacol Sci 1992;13:177-184. [PubMed: 1604710]

118. Koob GF, Sanna PP, Bloom FE. Neuroscience of addiction. Neuron 1998;21:467-476. [PubMed: 9768834]

119. Koob GF, Weiss F. Pharmacology of drug self-administration. Alcohol 1990;7:193-197. [PubMed: 1970479]

120. Kreek MJ, LaForge KS, Butelman E. Pharmacotherapy of addictions. Nat Rev Drug Discov 2002;1:710-726. [PubMed: 12209151] 
121. Lallemand F, De Witte P. SR147778, a CB1 cannabinoid receptor antagonist, suppresses ethanol preference in chronically alcoholized Wistar rats. Alcohol 2006;39:125-134. [PubMed: 17127132]

122. Lamarque S, Taghzouti K, Simon H. Chronic treatment with Delta(9)-tetrahydrocannabinol enhances the locomotor response to amphetamine and heroin. Implications for vulnerability to drug addiction. Neuropharmacology 2001;41:118-129. [PubMed: 11445192]

123. Le Foll B, Goldberg SR. Cannabinoid CB1 receptor antagonists as promising new medications for drug dependence. J Pharmacol Exp Ther 2005;312:875-883. [PubMed: 15525797]

124. Le Foll B, Goldberg SR. Rimonabant, a CB1 antagonist, blocks nicotine-conditioned place preferences. Neuroreport 2004;15:2139-2143. [PubMed: 15486497]

125. Le Foll B, Wiggins M, Goldberg SR. Nicotine pre-exposure does not potentiate the locomotor or rewarding effects of Delta-9-tetrahydrocannabinol in rats. Behav Pharmacol 2006;17:195-199. [PubMed: 16495727]

126. Ledent C, Valverde O, Cossu G, et al. Unresponsiveness to cannabinoids and reduced addictive effects of opiates in CB1 receptor knockout mice. Science 1999;283:401-404. [PubMed: 9888857]

127. Lepore M, Vorel SR, Lowinson J, et al. Conditioned place preference induced by delta 9tetrahydrocannabinol: comparison with cocaine, morphine, and food reward. Life Sci 1995;56:2073-2080. [PubMed: 7776834]

128. Lesscher HM, Hoogveld E, Burbach JP, et al. Endogenous cannabinoids are not involved in cocaine reinforcement and development of cocaine-induced behavioural sensitization. Eur Neuropsychopharmacol 2005;15:31-37. [PubMed: 15572271]

129. Lichtman AH, Sheikh SM, Loh HH, et al. Opioid and cannabinoid modulation of precipitated withdrawal in delta(9)-tetrahydrocannabinol and morphine-dependent mice. J Pharmacol Exp Ther 2001;298:1007-1014. [PubMed: 11504797]

130. Lopez-Moreno JA, Gonzalez-Cuevas G, Rodriguez de Fonseca F, et al. Long-lasting increase of alcohol relapse by the cannabinoid receptor agonist WIN 55,212-2 during alcohol deprivation. J Neurosci 2004;24:8245-8252. [PubMed: 15385608]

131. Lupica CR, Riegel AC. Endocannabinoid release from midbrain dopamine neurons: a potential substrate for cannabinoid receptor antagonist treatment of addiction. Neuropharmacology 2005;48:1105-1116. [PubMed: 15878779]

132. Maldonado R. Study of cannabinoid dependence in animals. Pharmacol Ther 2002;95:153-164. [PubMed: 12182962]

133. Maldonado R, Rodriguez de Fonseca F. Cannabinoid addiction: behavioral models and neural correlates. J Neurosci 2002;22:3326-3331. [PubMed: 11978807]

134. Maldonado R, Valverde O, Berrendero F. Involvement of the endocannabinoid system in drug addiction. Trends Neurosci 2006;29:225-232. [PubMed: 16483675]

135. Mallet PE, Beninger RJ. Delta9-tetrahydrocannabinol, but not the endogenous cannabinoid receptor ligand anandamide, produces conditioned place avoidance. Life Sci 1998;62:2431-2439. [PubMed: 9651110]

136. Martellotta MC, Cossu G, Fattore L, et al. Self-administration of the cannabinoid receptor agonist WIN 55,212-2 in drug-naive mice. Neuroscience 1998;85:327-330. [PubMed: 9622233]

137. Martin BR. Role of lipids and lipid signaling in the development of cannabinoid tolerance. Life Sci 2005;77:1543-1558. [PubMed: 15949820]

138. Martin BR, Compton DR, Thomas BF, et al. Behavioral, biochemical, and molecular modeling evaluations of cannabinoid analogs. Pharmacol Biochem Behav 1991;40:471-478. [PubMed: 1666911]

139. Martin M, Ledent C, Parmentier M, et al. Cocaine, but not morphine, induces conditioned place preference and sensitization to locomotor responses in CB1 knockout mice. Eur J Neurosci 2000;12:4038-4046. [PubMed: 11069600]

140. Mascia MS, Obinu MC, Ledent C, et al. Lack of morphine-induced dopamine release in the nucleus accumbens of cannabinoid CB(1) receptor knockout mice. Eur J Pharmacol 1999;383:R1-R2. [PubMed: 10594337] 
141. Masuzawa M, Nakao S, Miyamoto E, et al. Pentobarbital inhibits ketamine-induced dopamine release in the rat nucleus accumbens: a microdialysis study. Anesth Analg 2003;96:148-52. table. [PubMed: 12505941]

142. McDonald J, Schleifer L, Richards JB, et al. Effects of THC on behavioral measures of impulsivity in humans. Neuropsychopharmacology 2003;28:1356-1365. [PubMed: 12784123]

143. McGregor IS, Dam KD, Mallet PE, et al. Delta9-THC reinstates beer- and sucrose-seeking behaviour in abstinent rats: comparison with midazolam, food deprivation and predator odour. Alcohol Alcohol 2005;40:35-45. [PubMed: 15550450]

144. McGregor IS, Gallate JE. Rats on the grog: novel pharmacotherapies for alcohol craving. Addict Behav 2004;29:1341-1357. [PubMed: 15345269]

145. McGregor IS, Issakidis CN, Prior G. Aversive effects of the synthetic cannabinoid CP 55,940 in rats. Pharmacol Biochem Behav 1996;53:657-664. [PubMed: 8866969]

146. Melis M, Pistis M, Perra S, et al. Endocannabinoids mediate presynaptic inhibition of glutamatergic transmission in rat ventral tegmental area dopamine neurons through activation of CB1 receptors. J Neurosci 2004;24:53-62. [PubMed: 14715937]

147. Merritt LL, Martin BR, Walters C, et al. The endogenous cannabinoid system modulates nicotine reward and dependence. J Pharmacol Exp Ther 2008;326:483-492. [PubMed: 18451315]

148. Mokler DJ, Nelson BD, Harris LS, et al. The role of benzodiazepine receptors in the discriminative stimulus properties of delta-9-tetrahydrocannabinol. Life Sci 1986;38:1581-1589. [PubMed: 3010019]

149. Nava F, Carta G, Colombo G, et al. Effects of chronic Delta(9)-tetrahydrocannabinol treatment on hippocampal extracellular acetylcholine concentration and alternation performance in the $\mathrm{T}$ maze. Neuropharmacology 2001;41:392-399. [PubMed: 11522331]

150. Navarro M, Carrera MR, Fratta W, et al. Functional interaction between opioid and cannabinoid receptors in drug self-administration. J Neurosci 2001;21:5344-5350. [PubMed: 11438610]

151. Navarro M, Chowen J, Carrera MR, et al. CB1 cannabinoid receptor antagonist-induced opiate withdrawal in morphine-dependent rats. Neuroreport 1998;9:3397-3402. [PubMed: 9855288]

152. O'Brien, C. Drug addiction and drug abuse. In: Hardman, J.; Limbird, L.; Gilman, AG., editors. The Pharmacological Basis of Therapeutics. McGraw-Hill; New York: 2001. p. 621-642.

153. Oliva JM, Ortiz S, Palomo T, et al. Behavioural and gene transcription alterations induced by spontaneous cannabinoid withdrawal in mice. J Neurochem 2003;85:94-104. [PubMed: 12641731]

154. Parker LA, Gillies T. THC-induced place and taste aversions in Lewis and Sprague-Dawley rats. Behav Neurosci 1995;109:71-78. [PubMed: 7734082]

155. Parker LA, Mcdonald RV. Reinstatement of both a conditioned place preference and a conditioned place aversion with drug primes. Pharmacol Biochem Behav 2000;66:559-561. [PubMed: 10899370]

156. Patel S, Carrier EJ, Ho WS, et al. The postmortal accumulation of brain Narachidonylethanolamine (anandamide) is dependent upon fatty acid amide hydrolase activity. $\mathrm{J}$ Lipid Res 2005;46:342-349. [PubMed: 15576840]

157. Patel S, Rademacher DJ, Hillard CJ. Differential regulation of the endocannabinoids anandamide and 2-arachidonylglycerol within the limbic forebrain by dopamine receptor activity. $\mathrm{J}$ Pharmacol Exp Ther 2003;306:880-888. [PubMed: 12808005]

158. Pattij T, Janssen MC, Schepers I, et al. Effects of the cannabinoid CB1 receptor antagonist rimonabant on distinct measures of impulsive behavior in rats. Psychopharmacology (Berl) 2007;193:85-96. [PubMed: 17387457]

159. Pattij T, Vanderschuren LJ. The neuropharmacology of impulsive behaviour. Trends Pharmacol Sci 2008;29:192-199. [PubMed: 18304658]

160. Pertwee RG, Stevenson LA, Griffin G. Cross-tolerance between delta-9-tetrahydrocannabinol and the cannabimimetic agents, CP 55,940, WIN 55,212-2 and anandamide. Br J Pharmacol 1993;110:1483-1490. [PubMed: 8306090]

161. Pickel VM, Chan J, Kash TL, et al. Compartment-specific localization of cannabinoid 1 (CB1) and mu-opioid receptors in rat nucleus accumbens. Neuroscience 2004;127:101-112. [PubMed: 15219673] 
162. Pickel VM, Chan J, Kearn CS, et al. Targeting dopamine D2 and cannabinoid-1 (CB1) receptors in rat nucleus accumbens. J Comp Neurol 2006;495:299-313. [PubMed: 16440297]

163. Pierce RC, Bell K, Duffy P, et al. Repeated cocaine augments excitatory amino acid transmission in the nucleus accumbens only in rats having developed behavioral sensitization. J Neurosci 1996;16:1550-1560. [PubMed: 8778304]

164. Pistis, M.; Pillolla, G.; Luchicchi, A., et al. Inhibition of FAAH blocks the excitatory effects of nicotine on mesolimbic dopamine neurons via CB1 and PPAR-alpha receptors. 18th Annual Symposium on the Cannabinoids; Burlington, Vermont. 2008. p. 40

165. Pontieri FE, Monnazzi P, Scontrini A, et al. Behavioral sensitization to heroin by cannabinoid pretreatment in the rat. Eur J Pharmacol 2001b;421:R1-R3. [PubMed: 11516439]

166. Pontieri FE, Monnazzi P, Scontrini A, et al. Behavioral sensitization to WIN55212.2 in rats pretreated with heroin. Brain Res 2001a;898:178-180. [PubMed: 11292463]

167. Pontieri FE, Tanda G, Di Chiara G. Intravenous cocaine, morphine, and amphetamine preferentially increase extracellular dopamine in the "shell" as compared with the "core" of the rat nucleus accumbens. Proc Natl Acad Sci U S A 1995;92:12304-12308. [PubMed: 8618890]

168. Pontieri FE, Tanda G, Orzi F, et al. Effects of nicotine on the nucleus accumbens and similarity to those of addictive drugs. Nature 1996;382:255-257. [PubMed: 8717040]

169. Ramaekers JG, Kauert G, van Ruitenbeek P, et al. High-potency marijuana impairs executive function and inhibitory motor control. Neuropsychopharmacology 2006;31:2296-2303. [PubMed: 16572123]

170. Rice OV, Gordon N, Gifford AN. Conditioned place preference to morphine in cannabinoid CB1 receptor knockout mice. Brain Res 2002;945:135-138. [PubMed: 12113961]

171. Richter RM, Pich EM, Koob GF, et al. Sensitization of cocaine-stimulated increase in extracellular levels of corticotropin-releasing factor from the rat amygdala after repeated administration as determined by intracranial microdialysis. Neurosci Lett 1995;187:169-172. [PubMed: 7624019]

172. Riddle EL, Fleckenstein AE, Hanson GR. Role of monoamine transporters in mediating psychostimulant effects. AAPS J 2005;7:E847-E851. [PubMed: 16594636]

173. Riegel AC, Lupica CR. Independent presynaptic and postsynaptic mechanisms regulate endocannabinoid signaling at multiple synapses in the ventral tegmental area. J Neurosci 2004;24:11070-11078. [PubMed: 15590923]

174. Robbe D, Alonso G, Duchamp F, et al. Localization and mechanisms of action of cannabinoid receptors at the glutamatergic synapses of the mouse nucleus accumbens. J Neurosci 2001;21:109-116. [PubMed: 11150326]

175. Robinson TE, Berridge KC. The neural basis of drug craving: an incentive-sensitization theory of addiction. Brain Res Brain Res Rev 1993;18:247-291. [PubMed: 8401595]

176. Robinson TE, Berridge KC. Incentive-sensitization and addiction. Addiction 2001;96:103-114. [PubMed: 11177523]

177. Rodriguez de Fonseca F, Carrera MR, Navarro M, et al. Activation of corticotropin-releasing factor in the limbic system during cannabinoid withdrawal. Science 1997;276:2050-2054. [PubMed: 9197270]

178. Rodriguez de Fonseca F, Gorriti MA, Fernandez-Ruiz JJ, et al. Downregulation of rat brain cannabinoid binding sites after chronic delta 9-tetrahydrocannabinol treatment. Pharmacol Biochem Behav 1994;47:33-40. [PubMed: 8115426]

179. Rossetti ZL, Melis F, Carboni S, et al. Marked decrease of extraneuronal dopamine after alcohol withdrawal in rats: reversal by MK-801. Eur J Pharmacol 1991;200:371-372. [PubMed: 1782998]

180. Rothman RB, Baumann MH. Monoamine transporters and psychostimulant drugs. Eur J Pharmacol 2003;479:23-40. [PubMed: 14612135]

181. Rubino T, Forlani G, Vigano D, et al. Modulation of extracellular signal-regulated kinases cascade by chronic delta 9-tetrahydrocannabinol treatment. Mol Cell Neurosci 2004;25:355-362. [PubMed: 15033164]

182. Rubino T, Forlani G, Vigano D, et al. Ras/ERK signalling in cannabinoid tolerance: from behaviour to cellular aspects. J Neurochem 2005;93:984-991. [PubMed: 15857401] 
183. Rubino T, Massi P, Vigano D, et al. Long-term treatment with SR141716A, the CB1 receptor antagonist, influences morphine withdrawal syndrome. Life Sci 2000a;66:2213-2219. [PubMed: 10834304]

184. Rubino T, Vigano' D, Massi P, et al. Chronic delta-9-tetrahydrocannabinol treatment increases cAMP levels and cAMP-dependent protein kinase activity in some rat brain regions. Neuropharmacology 2000b;39:1331-1336. [PubMed: 10760375]

185. Rubino T, Vigano D, Massi P, et al. Changes in the cannabinoid receptor binding, G protein coupling, and cyclic AMP cascade in the CNS of rats tolerant to and dependent on the synthetic cannabinoid compound CP55,940. J Neurochem 2000c;75:2080-2086. [PubMed: 11032897]

186. Rubino T, Vigano D, Massi P, et al. Cellular mechanisms of Delta 9-tetrahydrocannabinol behavioural sensitization. Eur J Neurosci 2003;17:325-330. [PubMed: 12542669]

187. Sala M, Braida D. Endocannabinoids and 3,4-methylenedioxymethamphetamine (MDMA) interaction. Pharmacol Biochem Behav 2005;81:407-416. [PubMed: 15927242]

188. Salamone JD, McLaughlin PJ, Sink K, et al. Cannabinoid CB1 receptor inverse agonists and neutral antagonists: effects on food intake, food-reinforced behavior and food aversions. Physiol Behav 2007;91:383-388. [PubMed: 17521686]

189. Sanudo-Pena MC, Tsou K, Delay ER, et al. Endogenous cannabinoids as an aversive or counterrewarding system in the rat. Neurosci Lett 1997;223:125-128. [PubMed: 9089689]

190. Scherma M, Medalie J, Fratta W, et al. The endogenous cannabinoid anandamide has effects on motivation and anxiety that are revealed by fatty acid amide hydrolase (FAAH) inhibition. Neuropharmacology 2008a;54:129-140. [PubMed: 17904589]

191. Scherma M, Panlilio LV, Fadda P, et al. Inhibition of anandamide hydrolysis by URB597 reverses abuse-related behavioral and neurochemical effects of nicotine in rats. J Pharmacol Exp Ther 2008b;327(2):482-90. [PubMed: 18725543]

192. Schindler CW, Panlilio LV, Goldberg SR. Second-order schedules of drug self-administration in animals. Psychopharmacology (Berl) 2002;163:327-344. [PubMed: 12373434]

193. Sink KS, McLaughlin PJ, Wood JA, et al. The novel cannabinoid CB1 receptor neutral antagonist AM4113 suppresses food intake and food-reinforced behavior but does not induce signs of nausea in rats. Neuropsychopharmacology 2008;33:946-955. [PubMed: 17581535]

194. Solinas M, Goldberg SR, Piomelli D. The endocannabinoid system in brain reward processes. $\mathrm{Br}$ J Pharmacol 2008;154:369-382. [PubMed: 18414385]

195. Solinas M, Justinova Z, Goldberg SR, et al. Anandamide administration alone and after inhibition of fatty acid amide hydrolase (FAAH) increases dopamine levels in the nucleus accumbens shell in rats. J Neurochem 2006a;98:408-419. [PubMed: 16805835]

196. Solinas M, Panlilio LV, Antoniou K, et al. The cannabinoid CB1 antagonist N-piperidinyl-5-(4chlorophenyl)-1-(2,4-dichlorophenyl) -4-methylpyrazole-3-carboxamide (SR-141716A) differentially alters the reinforcing effects of heroin under continuous reinforcement, fixed ratio, and progressive ratio schedules of drug self-administration in rats. J Pharmacol Exp Ther 2003;306:93-102. [PubMed: 12660305]

197. Solinas M, Panlilio LV, Justinova Z, et al. Using drug-discrimination techniques to study the abuse-related effects of psychoactive drugs in rats. Nat Protoc 2006b;1:1194-1206. [PubMed: 17406402]

198. Solinas M, Panlilio LV, Tanda G, et al. Cannabinoid agonists but not inhibitors of endogenous cannabinoid transport or metabolism enhance the reinforcing efficacy of heroin in rats. Neuropsychopharmacology 2005;30:2046-2057. [PubMed: 15870833]

199. Solinas M, Scherma M, Fattore L, et al. Nicotinic alpha 7 receptors as a new target for treatment of cannabis abuse. J Neurosci 2007a;27:5615-5620. [PubMed: 17522306]

200. Solinas M, Scherma M, Tanda G, et al. Nicotinic facilitation of delta9-tetrahydrocannabinol discrimination involves endogenous anandamide. J Pharmacol Exp Ther 2007b;321:1127-1134. [PubMed: 17351107]

201. Solinas M, Tanda G, Justinova Z, et al. The endogenous cannabinoid anandamide produces delta-9-tetrahydrocannabinol-like discriminative and neurochemical effects that are enhanced by inhibition of fatty acid amide hydrolase but not by inhibition of anandamide transport. J Pharmacol Exp Ther 2007c;321:370-380. [PubMed: 17210800] 
202. Solinas M, Yasar S, Goldberg SR. Endocannabinoid system involvement in brain reward processes related to drug abuse. Pharmacol Res 2007d;56:393-405. [PubMed: 17936009]

203. Solinas M, Zangen A, Thiriet N, et al. Beta-endorphin elevations in the ventral tegmental area regulate the discriminative effects of Delta-9-tetrahydrocannabinol. Eur J Neurosci 2004;19:3183-3192. [PubMed: 15217374]

204. Soria G, Mendizabal V, Tourino C, et al. Lack of CB1 cannabinoid receptor impairs cocaine selfadministration. Neuropsychopharmacology 2005;30:1670-1680. [PubMed: 15742004]

205. Spano MS, Fattore L, Cossu G, et al. CB1 receptor agonist and heroin, but not cocaine, reinstate cannabinoid-seeking behaviour in the rat. Br J Pharmacol 2004;143:343-350. [PubMed: 15339858]

206. Spyraki C, Fibiger HC. A role for the mesolimbic dopamine system in the reinforcing properties of diazepam. Psychopharmacology (Berl) 1988;94:133-137. [PubMed: 3126522]

207. Substance Abuse and Mental Health Services Administration. Office of Applied Studies, NSDUH Series H-32, DHHS Publication No SMA 07-4293. Rockville, MD: 2007. Results from the 2005 National Survey on Drug Use and Health: National Findings.

208. Takahashi RN, Singer G. Self-administration of delta 9-tetrahydrocannabinol by rats. Pharmacol Biochem Behav 1979;11:737-740. [PubMed: 231789]

209. Takahashi RN, Singer G. Effects of body weight levels on cannabis self-injection. Pharmacol Biochem Behav 1980;13:877-881. [PubMed: 6259669]

210. Tanda G, Goldberg SR. Cannabinoids: reward, dependence, and underlying neurochemical mechanisms-a review of recent preclinical data. Psychopharmacology (Berl) 2003;169:115-134. [PubMed: 12827346]

211. Tanda G, Loddo P, Di Chiara G. Dependence of mesolimbic dopamine transmission on delta9tetrahydrocannabinol. Eur J Pharmacol 1999;376:23-26. [PubMed: 10440085]

212. Tanda G, Munzar P, Goldberg SR. Self-administration behavior is maintained by the psychoactive ingredient of marijuana in squirrel monkeys. Nat Neurosci 2000;3:1073-1074. [PubMed: 11036260]

213. Tanda G, Pontieri FE, Di Chiara G. Cannabinoid and heroin activation of mesolimbic dopamine transmission by a common mu1 opioid receptor mechanism. Science 1997;276:2048-2050. [PubMed: 9197269]

214. Taylor DA, Fennessy MR. Time-course of the effects of chronic delta 9-tetrahydrocannabinol on behaviour, body temperature, brain amines and withdrawal-like behaviour in the rat. J Pharm Pharmacol 1982;34:240-245. [PubMed: 6124598]

215. Thanos PK, Dimitrakakis ES, Rice O, et al. Ethanol self-administration and ethanol conditioned place preference are reduced in mice lacking cannabinoid CB1 receptors. Behav Brain Res 2005;164:206-213. [PubMed: 16140402]

216. Thiemann G, van der Stelt M, Petrosino S, et al. The role of the CB1 cannabinoid receptor and its endogenous ligands, anandamide and 2-arachidonoylglycerol, in amphetamine-induced behavioural sensitization. Behav Brain Res 2008;187:289-296. [PubMed: 17988751]

217. Thomas MJ, Beurrier C, Bonci A, et al. Long-term depression in the nucleus accumbens: a neural correlate of behavioral sensitization to cocaine. Nat Neurosci 2001;4:1217-1223. [PubMed: 11694884]

218. Thorat SN, Bhargava HN. Evidence for a bidirectional cross-tolerance between morphine and delta 9-tetrahydrocannabinol in mice. Eur J Pharmacol 1994;260:5-13. [PubMed: 7957626]

219. Thornton-Jones ZD, Vickers SP, Clifton PG. The cannabinoid CB1 receptor antagonist SR141716A reduces appetitive and consummatory responses for food. Psychopharmacology (Berl) 2005;179:452-460. [PubMed: 15821957]

220. Valjent E, Maldonado R. A behavioural model to reveal place preference to delta 9tetrahydrocannabinol in mice. Psychopharmacology (Berl) 2000;147:436-438. [PubMed: 10672638]

221. Valjent E, Mitchell JM, Besson MJ, et al. Behavioural and biochemical evidence for interactions between Delta 9-tetrahydrocannabinol and nicotine. Br J Pharmacol 2002;135:564-578. [PubMed: 11815392] 
222. Valverde O, Maldonado R, Valjent E, et al. Cannabinoid withdrawal syndrome is reduced in preproenkephalin knock-out mice. J Neurosci 2000;20:9284-9289. [PubMed: 11125007]

223. van der Laan JW, Eigeman L, Jansen van 't Land C. Benzodiazepines preferentially affect mesolimbic dopamine turnover in rats. Eur Neuropsychopharmacol 1992;2:425-431. [PubMed: 1362661]

224. van der Stelt M, Di Marzo V. The endocannabinoid system in the basal ganglia and in the mesolimbic reward system: implications for neurological and psychiatric disorders. Eur $\mathbf{J}$ Pharmacol 2003;480:133-150. [PubMed: 14623357]

225. Varvel SA, Martin BR, Lichtman AH. Lack of behavioral sensitization after repeated exposure to THC in mice and comparison to methamphetamine. Psychopharmacology (Berl) 2007;193:511519. [PubMed: 17497137]

226. Vela G, Ruiz-Gayo M, Fuentes JA. Anandamide decreases naloxone-precipitated withdrawal signs in mice chronically treated with morphine. Neuropharmacology 1995;34:665-668. [PubMed: 7566503]

227. Vengeliene V, Bilbao A, Molander A, et al. Neuropharmacology of alcohol addiction. Br J Pharmacol 2008;154:299-315. [PubMed: 18311194]

228. Verberne AJ, Taylor DA, Fennessy MR. Attenuation of delta 9-tetrahydrocannabinol-induced withdrawal-like behaviour by delta 9-tetrahydrocannabinol. Psychopharmacology (Berl) 1981;73:97-98. [PubMed: 6262850]

229. Vigano D, Grazia CM, Rubino T, et al. Chronic morphine modulates the contents of the endocannabinoid, 2-arachidonoyl glycerol, in rat brain. Neuropsychopharmacology 2003;28:1160-1167. [PubMed: 12637958]

230. Vigano D, Valenti M, Cascio MG, et al. Changes in endocannabinoid levels in a rat model of behavioural sensitization to morphine. Eur J Neurosci 2004;20:1849-1857. [PubMed: 15380006]

231. Vinklerova J, Novakova J, Sulcova A. Inhibition of methamphetamine self-administration in rats by cannabinoid receptor antagonist AM 251. J Psychopharmacol 2002;16:139-143. [PubMed: 12095072]

232. Welch SP. Characterization of anandamide-induced tolerance: comparison to delta 9-THCinduced interactions with dynorphinergic systems. Drug Alcohol Depend 1997;45:39-45. [PubMed: 9179505]

233. Wiley JL, Golden KM, Ryan WJ, et al. Evaluation of cannabimimetic discriminative stimulus effects of anandamide and methylated fluoroanandamide in rhesus monkeys. Pharmacol Biochem Behav 1997;58:1139-1143. [PubMed: 9408225]

234. Wiley JL, Huffman JW, Balster RL, et al. Pharmacological specificity of the discriminative stimulus effects of delta 9-tetrahydrocannabinol in rhesus monkeys. Drug Alcohol Depend 1995a;40:81-86. [PubMed: 8746928]

235. Wiley JL, LaVecchia KL, Karp NE, et al. A comparison of the discriminative stimulus effects of Delta(9)-tetrahydrocannabinol and O-1812, a potent and metabolically stable anandamide analog, in rats. Exp Clin Psychopharmacol 2004;12:173-179. [PubMed: 15301634]

236. Wiley JL, Lowe JA, Balster RL, et al. Antagonism of the discriminative stimulus effects of delta 9-tetrahydrocannabinol in rats and rhesus monkeys. J Pharmacol Exp Ther 1995b;275:1-6. [PubMed: 7562536]

237. Wiley JL, Martin BR. Effects of SR141716A on diazepam substitution for delta9tetrahydrocannabinol in rat drug discrimination. Pharmacol Biochem Behav 1999;64:519-522. [PubMed: 10548265]

238. Wiley JL, Ryan WJ, Razdan RK, et al. Evaluation of cannabimimetic effects of structural analogs of anandamide in rats. Eur J Pharmacol 1998;355:113-118. [PubMed: 9760024]

239. Wise RA. Dopamine, learning and motivation. Nat Rev Neurosci 2004;5:483-494. [PubMed: 15152198]

240. Wise RA, Bozarth MA. A psychomotor stimulant theory of addiction. Psychol Rev 1987;94:469492. [PubMed: 3317472]

241. Wolf ME, Sun X, Mangiavacchi S, et al. Psychomotor stimulants and neuronal plasticity. Neuropharmacology 2004;47:61-79. [PubMed: 15464126] 
242. Xi ZX, Gilbert JG, Peng XQ, et al. Cannabinoid CB1 receptor antagonist AM251 inhibits cocaine-primed relapse in rats: role of glutamate in the nucleus accumbens. J Neurosci 2006;26:8531-8536. [PubMed: 16914679]

243. Yokel, RA. Intravenous self-administration: response rates, the effects of pharmacological challenges, and drug preference. In: Bozarth, MA., editor. Methods of assessing the reinforcing properties of abused drugs. Springer-Verlag; New York: 1987. p. 1-33.

244. Young, AM.; Herling, S. Drugs as Reinforcers: Studies in Laboratory Animals. In: Goldberg, SR.; Stolerman, IP., editors. Behavioral Analysis Of Drug Dependence. Academic Press; Orlando: 1986. p. 9-67.

245. Young AM, Herling S, Woods JH. History of drug exposure as a determinant of drug selfadministration. NIDA Res Monogr 1981;37:75-88. [PubMed: 6798469]

246. Young AM, Woods JH. Maintenance of behavior by ketamine and related compounds in rhesus monkeys with different self-administration histories. J Pharmacol Exp Ther 1981;218:720-727. [PubMed: 7264955]

247. Zangen A, Solinas M, Ikemoto S, et al. Two brain sites for cannabinoid reward. J Neurosci 2006;26:4901-4907. [PubMed: 16672664]

248. Zhang PW, Ishiguro H, Ohtsuki T, et al. Human cannabinoid receptor 1: 5' exons, candidate regulatory regions, polymorphisms, haplotypes and association with polysubstance abuse. Mol Psychiatry 2004;9:916-931. [PubMed: 15289816]

249. Zimmer A, Valjent E, Konig M, et al. Absence of delta -9-tetrahydrocannabinol dysphoric effects in dynorphin-deficient mice. J Neurosci 2001;21:9499-505. [PubMed: 11717384]

250. Zuo L, Kranzler HR, Luo X, et al. CNR1 variation modulates risk for drug and alcohol dependence. Biol Psychiatry 2007;62:616-626. [PubMed: 17509535] 